\title{
Una proyección gráfica de la palabra: Los dibujos "abstractos" y vibracionistas de Federico García Lorca
}

\section{A graphical projection of the word: the "abstract" and vibrationist drawings of Federico García Lorca}

\author{
José Luis PLAZA CHILLÓN \\ Universidad de Granada
}

Recibido: 23-IV-2014 / Aceptado: 30-V-2014

Resumen: Las relación entre poesía y pintura en la década de 1920 adquirirá una especial dimensión en España desconocida hasta entonces. Uno de los artífices más sobresalientes será Federico García Lorca que comenzará a concebir una serie de dibujos que él mismo define como poemas y "puras abstracciones líricas". Lorca se plantea las exigencias de una moderna representación espacial y de una elaboración puramente intelectual con el claro sentido de una nueva escritura reflejada especialmente en sus poco conocidos "poemas en prosa". Busca una plena autonomía de la obra creada, con aportaciones que en muchos casos eran una rareza o no existían en el panorama artístico español de aquellos años. En todo ello planea el sabio magisterio del pintor Rafael Pérez Barradas y las influencias de Dalí y Miró.

Palabras clave: Poesía, Pintura, Dibujos, Abstracción, Vibracionismo, Sinestesia, Barradas, Dalí, Miró.

ABSTRACT: The relationship beetween poetry and painting in the 1920s to acquire a special dimension hither to unknown in Spain. One of the most outstanding architects Federico García Lorca will begin to devise a series of drawings which he defines as poems and "pure lyrical abstractions". Lorca considers the demands of a modern spatial represetation and the demands of a purely intellectual demonstration with the clear sense of a new writing specially reflected in his little known "prose poems". He looks for complete autonomy in his created work, with contributions that in most cases were a rarity or didn't exist in the Spanish artistic scene on those years. And the wise teaching of the painter Rafael Pérez Barradas is evident in all his work.

Key words: Poetry, Paintings, Drawings, Abstraction, Vibrationism, Synesthesia, Barradas, Dalí, Miró

"Quién deja un trazo, deja una herida"

(Henri Michaux)
Cuando más intensas se volvían las relaciones entre poesía y pintura, una vez derrumbadas las fronteras conceptuales que separaban ambas artes en fechas (1925-1928) en las que Salvador Dalí exaltaba a Picasso 
como el mayor poeta existente, Lorca empieza a crear y concebir poemas lineales, o sea, dibujos que se definen como poemas y que son "puras abstracciones líricas". Dalí se muestra contentísimo de que a Lorca le entusiasme Miró, e insiste en que los únicos poetas nuevos son los pintores. Cuarenta años después de la muerte del poeta granadino, Miró le correspondía con estas palabras: “Los dibujos de Lorca me parecen obra de un poeta, que es el mejor elogio que puedo hacer a

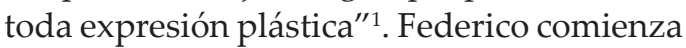
a plantearse las exigencias de una moderna representación espacial, de una elaboración puramente intelectual con el claro sentido de una nueva escritura reflejada ejemplarmente en los "poemas en prosa" 2 , buscando una plena autonomía de la obra creada, con aportaciones que en muchos casos eran una rareza o no existían en el panorama artístico español de aquellos años. La abstracción sería llevada hasta sus últimas consecuencias en algunas creaciones lorquianas. Éste era un lenguaje muy poco difundido cuando no rechazado, sin embargo, Federico lo señala y utiliza como una posibilidad de expresión, y hace de él un lenguaje propio. Aunque matiza su alejamiento de la deshumanización del arte, sus dibujos son "humanísimos porque casi todos van a dar con su flechita en el corazón". El poeta sentía un profundo rechazo por la pintura directa, "que no es sino una angustiosa lucha con las formas en la que el pintor sale siempre vencido y la obra muer-

${ }^{1}$ J. MIRÓ, “Composición”, Trece de nieve, no 1-2, 1976, pp. 156-157.

${ }^{2}$ A los seis poemas que forman el corpus ineludible y casi con seguridad de los Poemas en prosa ("Santa Lucía y San Lázaro", "Nadadora sumergida", "Suicidio en Alejandría", "Amantes asesinados por una perdiz", "Degollación de los inocentes" y "Degollación del Bautista"), se han sumado: "La muerte de la madre de Charlot", el esbozo de "Coeur azul-corazón bleau" y "La gallina. Cuento para niños tontos"; en J. HUÉLAMO KOSMA, "Los poemas en prosa: Lorca ante la encrucijada", en A. SORIA OLMEDO, M.J., SÁNCHEZ MONTES, J. VARO ZAFRA (coords.), Federico García Lorca. Clásico / Moderno (1898-1998), Granada, 2000, p. 110. Un análisis teórico de este género literario lo encontramos en, M.V. UTRERA TORREMOCHA, Teoría del poema en prosa, Sevilla, 1999. ta. En estas abstracciones mías veo yo realidad creada que se une con la realidad que nos rodea..., hay que unir la abstracción" ${ }^{3}$.

Tanto sus dibujos como la poesía que ahora escribe son puros. Federico se muestra más complejo y enigmático que nunca, probablemente llevado por el impulso también "puro" del instinto. Como señaló José Caballero, pintor, amigo y colaborador del poeta, el abstraccionismo del granadino llega a cotas inusitadas, que antecede al gesto pictórico expresionista de los neoyorquinos y los informalistas europeos, coincidiendo en conceptos de trazos verticales violentos, entramados y rupturas de superficies, muy parecidos a los realizados por Hans Hartung treinta años después ${ }^{4}$. En este sentido el dibujo Bosque sexual (1932) (Fig. 1), que probablemente enviara a José Bergamín para su inclusión como ilustración gráfica en la primera edición de Poeta en Nueva York ${ }^{5}$. Lorca realiza de manera gestual un poema gráfico expresionista, provocando auténtico vitalismo en los trazos verticales que simulan estilizadas figuras masculinas y femeninas definidas por su sexo. Superpone y oculta elementos puramente fisiológicos e iconográficamente surrealistas, me refiero a los labios y ojos que se esconden en sus besos, mientras se observan y vigilan entre las sinuosas líneas trazadas con seguridad, y marcadamente violentas. Líneas que a modo de máscara parecen ocultar el rostro del poeta, que a modo de voyeur, se esconde en el enmarañado "bosque sexual", donde puede disimular sin peligro a ser descubierto su verdadero placer. Un bosque que por un momento camufla su pasión, aunque paradójicamente sirva también como cortina castradora de la auténtica verdad, la neoyor-

${ }^{3}$ F. GARCÍA LORCA, Obras completas, Madrid, 1989, T. III, p. 970.

${ }^{4}$ J. CABALLERO, "Notas de trabajo sobre los dibujos lorquianos", Boletín de la fundación Federico García Lorca, no 12, 1992, pp. 49-57.

${ }^{5} \mathrm{El}$ dibujo se reprodujo por vez primera en F. GARCÍA LORCA, Poeta en Nueva York, México, 1940, pp. 6465. 
quina "verdad de las sepulturas". Similares a éste destacamos Parque y Parque de la línea envolvente (1935-36), con algunos elementos figurativos, como ramajes o gotas de agua, aunque no se aparta de la envolvente abstracción que los domina, donde la marcada línea que los une sugiere el principio y fin de la misma. Ambos se aproximan a las propuestas plásticas que por estos años realiza el admirado Joan Miró, con el que confluye poéticamente, como podremos comprobar al final de este artículo.

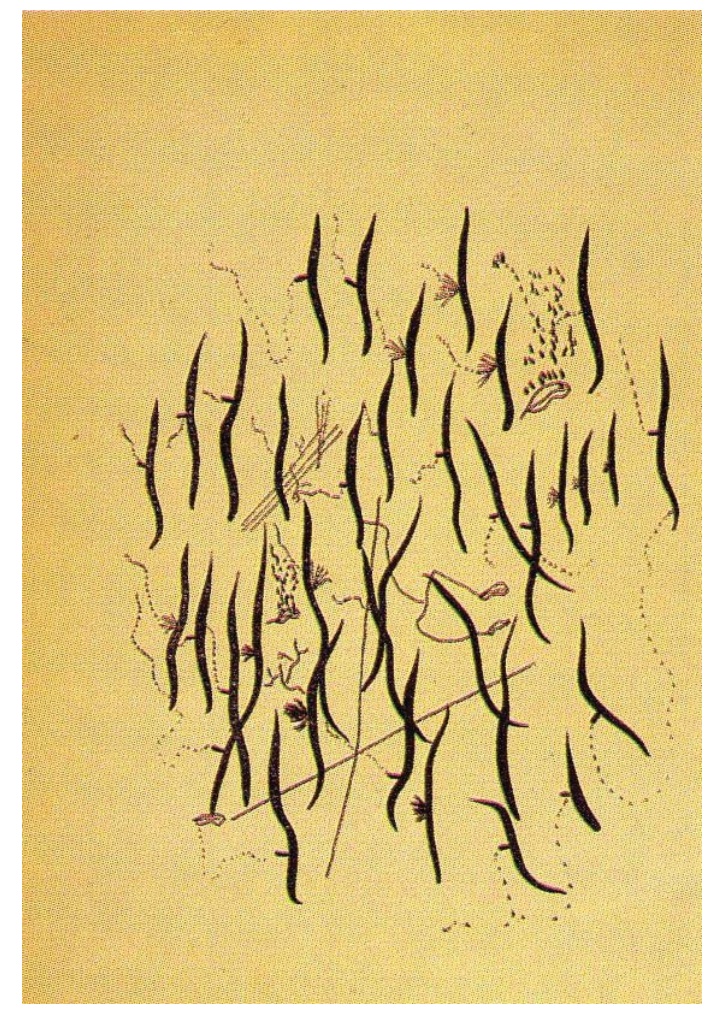

- Fig. 1. Federico García Lorca, Bosque sexual, (ca. 1932). ¿Tinta sobre papel? Medidas y paradero desconocidos. Ejemplar de la Fundación Federico García Lorca, Madrid.

\section{EL MAGISTERIO DE BARRADAS: VI- BRACIONISMO Y POESÍA}

Dalí, Miró y Picasso habían considerado a los pintores modernos como los auténticos poetas; los dos primeros se refirieron precisamente de esta manera a García Lorca. Así fue corroborado por el pintor uruguayo Rafael Pérez Barradas, uno de los grandes animadores de la vanguardia y la modernidad en España, pilar básico en la formación teórico-plástica de Federico ${ }^{6}$. Después del apoteósico éxito del granadino con la exposición de sus dibujos en las galerías Dalmau de Barcelona, mantendrá una animada correspondencia con sus amigos catalanes, especialmente con Dalí y Gasch, pero su relación se tornará especial con Barradas. En 1927 Lorca envía al uruguayo una carta con un dibujo, que adquiere una dimensión significativa dentro del conjunto de la obra plástica lorquiana. Se trata de Herido en el Alba (1927) (Fig. 2); dicha composición representa ese esfuerzo común que están realizando los amigos catalanes, por un lado, a la vez que participa de la misión y el deber social que debe cumplir el artista verdadero. En la citada carta, Lorca plantea a Barradas su intimidad creadora, y se refiere al dibujo como un poema, otra constatación de la ruptura de los límites entre poesía y pintura. El dibujo tiene una importancia singular para el poeta, no sólo por la amistad que le unía con el pintor sudamericano, sino y sobre todo, por la admiración tan profunda que le profesaba como artista. Su influencia es vital para comprender gran parte de las creaciones plásticas lorquianas, sobre todo la referida a la iconografía de marineros, clowns y gitanos ${ }^{7}$. Lorca y Barradas se conocieron en Madrid en 1919 con motivo de un trabajo coyuntural para el granadino, que fue la realización de los figurines para El maleficio de la mariposa, estrenada en el teatro Eslava en $1920^{\circ}$. Este fue el comienzo de una fructífera colaboración plástica con resultados muy satisfactorios ${ }^{9}$.

${ }^{6}$ M. GARCÍA GUATAS, “Barradas: Ars longa Vita brevis", Artigrama, no 17, 2002, pp. 49-70.

${ }^{7}$ R. PEREDA, Barradas, Montevideo, 1989, pp. 208211.

${ }^{8}$ A. PELÁEZ MARTÍN, "Barradas en el teatro de Arte: tradición y vanguardia (1917-1925)” en J. BRIHUEGA y C. LOMBA (eds.), Barradas. Catálogo de la exposición., Madrid, 1992, pp. 83-97.

${ }^{9}$ P. GARCÍA-SEDAS, “De El maleficio de la mariposa al vuelo de Pegaso: Barradas-Lorca-Dalí", en Salvador Dalí y Federico García Lorca. La persistencia de la memoria. 
Quizá no haya sido suficientemente valorado este artista, que había recorrido Europa empapándose de los ambientes de la modernidad. Barradas creó un movimiento artístico esencial para la vanguardia española: el vibracionismo, decisivo en la formación plástica de Lorca, que se plasma, como veremos, especialmente en aquellas composiciones que muestran un afán de movimiento estático.

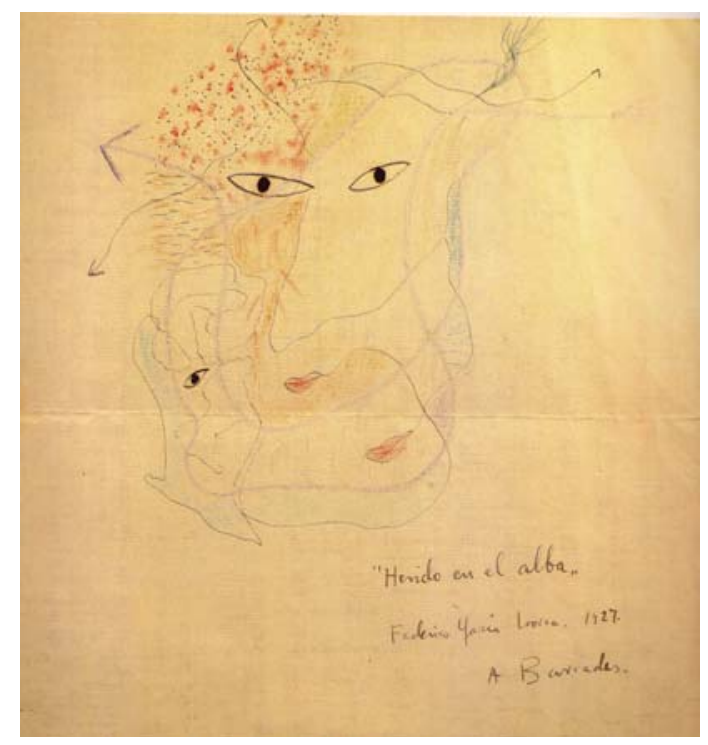

- Fig. 2. Federico García Lorca, Herido en el alba (Granada, 1927). Tinta y lápices de color sobre papel. 140 x 120 mm. Colección Antonia Sicardi Laínez, Montevideo.

El vibracionismo tuvo un desarrollo lingüístico y cronológico preciso, aunque nunca se teorizaría por escrito, al margen de referencias en catálogos de exposiciones o críticas periodísticas. Dicho movimiento partía de la incorporación fragmentaria de distintos lenguajes de la vanguardia europea y desembocaría, tras su síntesis, en diversas líneas de expresión ${ }^{10}$. Las bases fundacionales fueron el cubismo y el futu-

Catálogo de la exposición, Barcelona, 2004, pp. 173187.

${ }^{10}$ Véase, Ismos: arte de vanguardia (1910-1936) en España. Catálogo de la exposición, Madrid, 1996 y La generación del 14 entre el novecentismo y la vanguardia (19061926). Catálogo de la exposición, Madrid, 2002. rismo; aunque tal vez esto sería reducirlo demasiado. Una simple selección de imágenes producidas hasta final de 1918 por la vanguardia internacional bastaría para establecer una dinámica de extracción de elementos combinatorios que haría desembocar en sintonías con todos los extremos recorridos por el vibracionismo barradiano en artistas como Gleizes, Picabia, Severini, Depero, Carrá, Marinetti; pero ante todo en Sonia y Robert Delaunay, con su propuesta del simultaneísmo, que intentaba obtener la intemporalidad, o sea, "la unidad de expresión mediante la unidad de los medios técnicos" ${ }^{\prime 11}$. Esta corriente encuentra en Barradas un lenguaje que expresa la esencia visual y antropológica de la cultura urbana contemporánea, ejemplificado en ciudades en las que había vivido como Milán, París o Barcelona, que ya habían sido propuestas por la estética "maquinista" presente en diversas poéticas contemporáneas, con toda una iconografía que traza la extensa alegoría de la modernidad: colores, planos, coches, tranvías, rótulos, escaparates, collages periodísticos, etc. Se constituye así el vibracionismo como la primera etapa sólida de su evolución artística ${ }^{12}$. A Barradas le interesó el efecto visual de la pintura futurista que reutilizaba el lenguaje cubista, $\mathrm{y}$ que en este movimiento genuinamente suyo consistió en la captación del continuo tránsito entre sujeto y objeto, entre conciencia y mundo circundante. Su vibracionismo se puede considerar una forma de vitalismo estético. Las obras se reconocen porque poseen su semejante grado de intensidad emocional; así en algunos dibujos se observa un vibracionismo de formas libres y gestuales, no geométricas, encabalgadas como fragmentos en la escena que describen.

\footnotetext{
${ }^{11}$ R. RISS (ed.), Sonia y Robert Delaunay. Catalogo de la exposición, Barcelona, 2006, pp. 94-96.

${ }^{12} \mathrm{~J}$. BRIHUEGA, “Saturno en el sifón, Barradas y la vanguardia española", en J. BRIHUEGA y C. LOMBA (eds.), Op.cit., pp. 20-22.
} 
Barradas fue un pintor que prefirió estar rodeado de poetas. Mucho escribieron los poetas sobre Barradas, pero del pintor siempre se habló en metáfora. Para caracterizarlo se buscaba un lema imaginativo que dejara de manifiesto tanto la singularidad del aludido como la originalidad del autor del rótulo. Poetas que se citaron con Barradas fueron Guillermo de Torre ${ }^{13}$, Vando-Villar, Gutiérrez Gili, García Lorca, Benjamín Jarnés, Moreno Villa, Pedro Garfias o Juan Ramón Jiménez, que lo exaltaban siempre como pintor. El origen de Barradas remite a la mesa de un café y a un grupo de apasionados contertulios; ser pintor autodidacta, como ser intelectual de café, en el cruce de los siglos XIX y XX, era estar situado estructuralmente con respecto a la creación ${ }^{14}$. Gracias a su acción enérgica y contundente, se iba destruyendo el rancio pasado artístico español, ayudando a edificar cosas con capacidad de porvenir, como él mismo intentó representar, en una España todavía sumida en un aletargado y atraso plástico ${ }^{15}$. Barradas alcanzó fama rápida entre intelectuales madrileños y catalanes; precisamente en 1927 formaron el célebre Ateneillo de L'Hospitalet, donde se reunían Guillermo Díaz Plaja, Lluis Montayá, Gasch, Dalí y Lorca; allí se discutía, se hablaba o se creaba en un ambiente abierto y libre, siempre dentro del espíritu inquieto que le caracterizó ${ }^{16}$. Aplaudido en sus aciertos y comprendido en sus vacilaciones, le fueron dedicadas muchas páginas

${ }_{13}$ Guillermo de Torre pudo haber sido el nexo de unión entre Barradas y García Lorca ya que se conocían desde 1915. C. GARCÍA (ed.), Federico García Lorca / Guillermo de Torre. Correspondencia y amistad, Madrid / Frankfurt am Maim, 2009, pp. 35-36.

${ }^{14}$ E. CARMONA, "Rafael Barradas y el Arte Nuevo en España (1917-1925)", en J. BRIHUEGA y C. LOMBA (eds.), Op.cit., pp. 107-110.

${ }^{15} \mathrm{~J}$. de la ENCINA, “Exposición Barradas", España, 20-III-1920, pp. 212-213, M. ABRIL, "Barradas", Ultra, no $2,1921, \mathrm{~s} / \mathrm{p}$

16 F. MIRALLES,“Barradas, entre Barcelona y L'Hospitalet", en J. BRIHUEGA y C. LOMBA (eds.), Op.cit., pp. 99-106. de periódicos y revistas; incluso su muerte fue llorada en el mundo del arte y la intelectualidad de la España de 1929, por su espíritu de entrega y esa obra tan subyugante que legó, quedando impresa en muchos artistas del momento, además de ser considerada como un valor fundamental en la evolución de la pintura española contemporánea ${ }^{17}$.

García Lorca y Barradas conectaron amistosa y estéticamente; el uruguayo le influyó en la forma de componer sus dibujos, así como a diseñar figurines y bocetos escenográficos; recordemos, en este sentido, la célebre Sesión de Títeres de 1923 en la casa granadina de los García Lorca. Pero insistimos en que en el arte del dibujo Barradas fue un acicate para el lanzamiento del poeta ${ }^{18}$, además de otros artistas destacados como el escultor Alberto, Manuel Ángeles Ortiz o Dalí, los cuales se dejaron seducir por su particular arte. Federico fue el más beneficiado de esta influencia, que se manifestará especialmente en los líricos dibujos de payasos, arlequines y clowns.

Existe un interesante documento que arroja un nuevo testimonio de amistad entre el granadino y el uruguayo; se trata de un folio suelto en cuyo reverso Lorca estampó un "payaso llorando" cogiendo el pétalo de una flor, cuyo tallo son sus propias lágrimas, y un breve poema inédito fechado en 1925 (Fig. 3); mientras que en la otra cara Barradas ha dibujado el rostro de la actriz Catalina Bárcena (protagonista de El maleficio de la mariposa) con estética "clownista" y que Lorca concluye dibujando el rostro completo, convirtiéndose en un trabajo compartido y en un significativo gesto de sus múltiples y fructíferas colabo-

${ }^{17}$ G. de TORRE, "Adiós a Barradas (Noticias sobre su vida y su muerte)", La Gaceta literaria, no 58, 1929, p.5. B. JARNÉS, "Rafael Barradas", Revista de Occidente, no 3, 1929, pp. 389-391.

${ }^{18}$ J. ORTIZ SALARAGUI, “Federico García Lorca y Rafael Barradas", Romance, nº 19, 1940, pp. 8-9. 
raciones $^{19}$. La influencia fue mutua, Barradas también se dejó embaucar por la poesía del granadino, con la que impregnaba sus lienzos, reflejando la exquisita calidad de su sentimiento poético que anidaba en lo más hondo de su alma ${ }^{20}$. La huella de amistad entre ambos artistas llegó más allá de la vida y de la muerte. Lorca tuvo en gran estima a Barradas, y así lo reconocería en una entrevista de 1933: " ¿Sabe usted lo que pensaba en Montevideo mientras los fotógrafos me enfocaban y los periodistas me hacían preguntas?... Pues en Barradas, el gran pintor uruguayo a quien uruguayos y españoles hemos dejado morir de hambre [...] Todo eso que me daban a mi se lo negaban a él..."21. Este sentimiento fue corroborado, cuando el 30 de enero de 1934, en una estancia de dos semanas en Montevideo, fue al encuentro del amigo al cementerio del Buceo ${ }^{22}$. (Fig. 4).

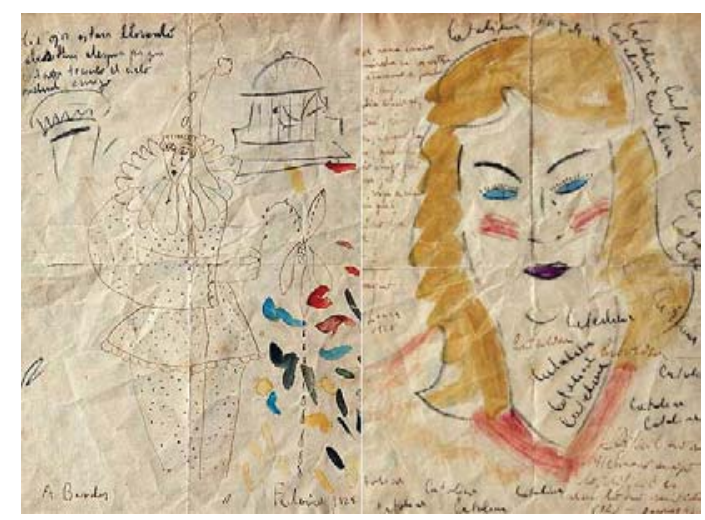

- Fig. 3. Federico García Lorca y Rafael Pérez Barradas, Dibujo de payaso llorando, cogiendo un pétalo de flor, cuyo tallo son sus propias lágrimas (1925). Realizado al dorso de un folio donde aparece dibujado el rostro de Catalina Bárcena por Rafael Pérez Barradas, en el que también interviene García Lorca. Colección privada, Barcelona.

${ }^{19}$ D. VERDÚ, “Un Lorca a cuatro manos”, El País, 16-III-2008, p. 42.

${ }^{20}$ S. GASCH, "Rafael Barradas y Federico García Lorca en el recuerdo", Bellas Artes, no 29,1974, pp. 8-10.

${ }^{21}$ F. GARCÍA LORCA, Obras completas, T. III, p. 152.

${ }^{22}$ M. GARCÍA POSADA, "García Lorca en Uruguay", Triunfo, no 21-22, 1982, pp. 82-88.

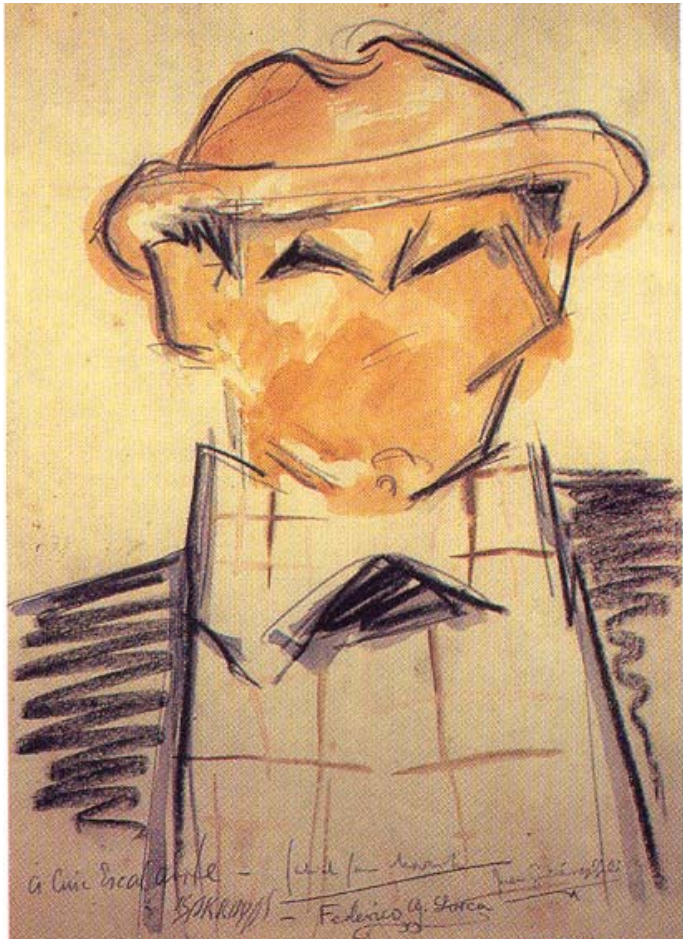

- Fig. 4. Rafael Pérez Barradas, García Lorca (1922). Acuarela y lápiz de color negro. 33×23 $\mathrm{cm}$. Museo Nacional de Artes Plásticas y Visuales, Montevideo (Uruguay).

El dibujo Herido en el Alba resume la idea lorquiana de lo que significa un poema visual cuando se refiere a sus dibujos como "poesía pura" o "plástica pura" a la vez (Fig. 2); así se lo aclaraba a Gasch cuando afirmaba que ahora empezaba a "escribir y a dibujar poesías como esta que le envío dedicada. Cuando un asunto es demasiado largo tiene poéticamente una emoción manida, lo resuelvo con los lápices. Esto me alegra y divierte de manera extraordinaria" ${ }^{23}$. Lorca lo funde todo en este dibujo; está invadido por suaves colores que delimitan los dos rostros que se superponen, con lívidos cabellos y reiteradas flechas que salen de los rostros. Contiene una emoción de signo lírico, semejante a la que está en el origen de un poema, que plasma plásticamente la misma emoción. Esa estilización cubo-futurista o vibracionista de raíz barradiana, cercana a los postulados del cubismo lírico o la pin-

\footnotetext{
${ }^{23}$ F. GARCÍA LORCA, Obras completas, T. III, p. 953.
} 
tura-poética defendidos por Francisco Bores $^{24}$, adquiere una auténtica aspiración espiritual, conseguida mediante la reducción a puras líneas abstractas, pero sin olvidar el reflejo de la atormentada vida interior del poeta y de la que se distanciaba precisamente con los dibujos humanos. Quizá ese sea el motivo de las siguientes palabras escritas a Gasch, donde le confiesa su miedo al sueño o a la temida vigilia: "...Yo nunca me aventuro en terrenos que no son del hombre, porque vuelvo tierra atrás en seguida y rompo casi siempre el producto de mi viaje. Cuando hago una cosa de pura abstracción, siempre tiene (creo yo) un salvoconducto de sonrisas y un equilibrio bastante humano. [...] Yo estoy y me siento con pies de plomo en el arte. El abismo y el sueño lo temo en la realidad de mi vida, en el amor, en el encuentro cotidiano con los demás. Eso sí que es terrible y fantástico" 25 .

A Barradas le entusiasmó el dibujo, y contestó al poeta con una misiva desde el Ateneillo de L'Hospitalet: "Recibí tu carta y el magnífico, deliciosísimo poema (Herido al Alba). Este me dice tantas cosas que no sé como expresarlas. Es aquello de ponerle a uno la carne de gallina" ${ }^{26}$. Además promete enseñarlo al resto del grupo, y al calificarlo de poema acepta el juego conceptual y estético del poeta, recayendo en la importancia dada al trabajo creativo como "juego encantador de la emoción poética". Herido en el Alba alude también a un tema obsesivo, constante y premonitorio en la obra literaria lorquiana, la muerte en el alba, filo temporal agónico del que Federico fue víctima un amanecer de agosto de 1936. Pero esta muerte manifiesta o herida permanente se refiere más al amor, siempre camuflado por máscaras superpuestas con flechas sexuales, que en este poema visual queda debidamente dibujado.

${ }^{24}$ J. M. BONET, "Para un mapa de la pintura del 27", en E. CARMONA (ed.), Trazo y verbo. La pintura del 27. Catálogo de la exposición, Málaga, 2005, pp. 23-31.

${ }^{25}$ F. GARCÍA LORCA, Obras completas, T. III, p. 967.

${ }^{26}$ A. RODRIGO, García Lorca en Cataluña, Barcelona, 1975, pp. 134-135.

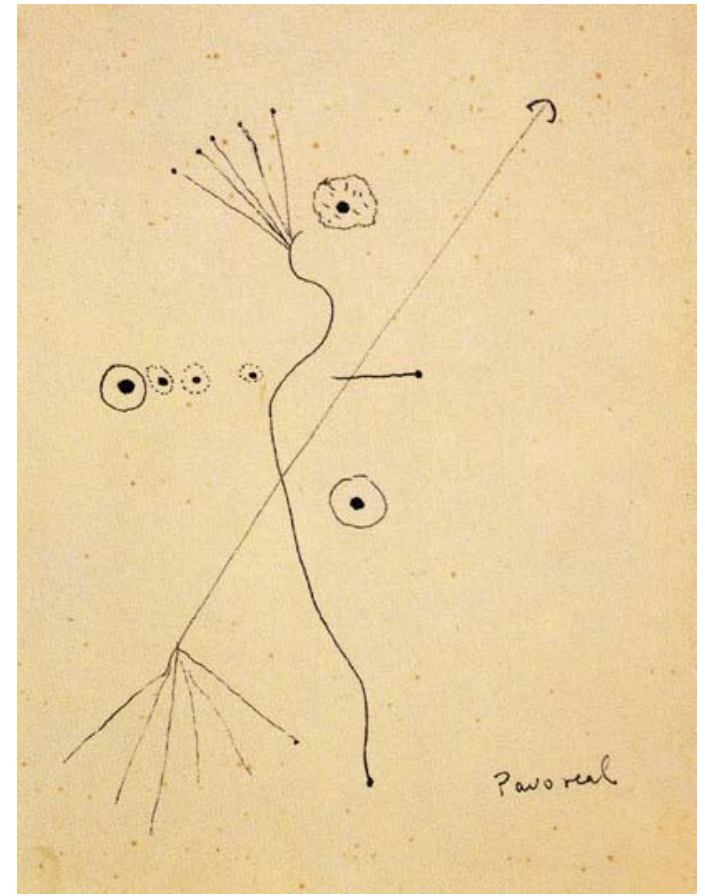

- Fig. 5. Federico García Lorca. Pavo real (1927). Tinta china sobre papel verjurado recortado. 157 x 120 mm. Colección Particular, Madrid.

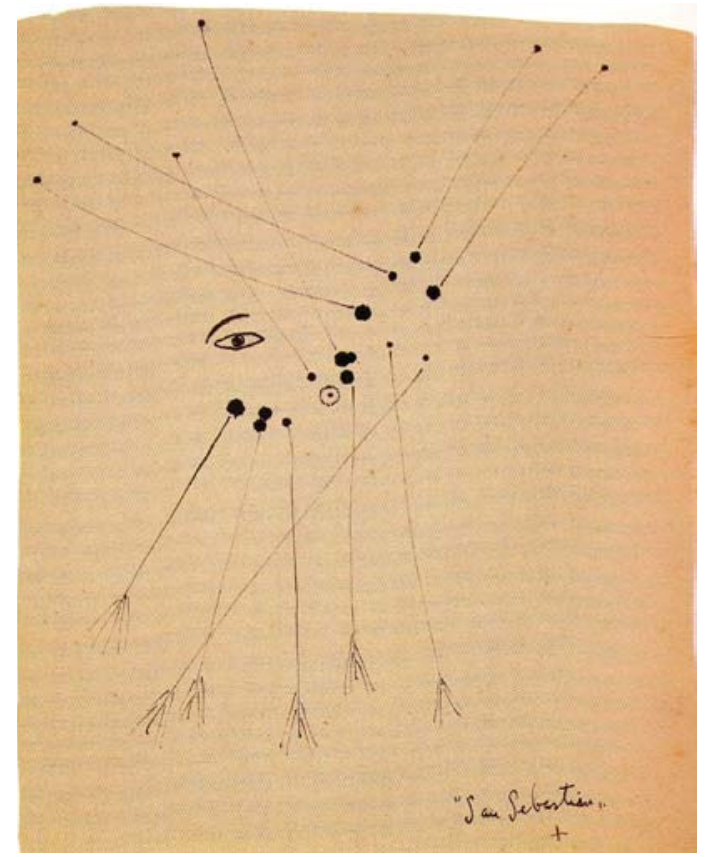

- Fig. 6. Federico García Lorca. San Sebastián (1927). Tinta china sobre papel verjurado recortado. 155 x 125 mm. Colección Particular, Madrid. 
Lorca trasciende la realidad a través de estos dibujos tan simples de ejecución como complejos en su proyección interior, ya que no se queda en lo puramente objetual, que por otro lado había formado parte de la plasmación plástica en la exposición individual de 1927, sino que profundizará en el significado de los mismos; así un payaso, una pecera, un florero o un retrato se proyectan en diversos planos, o incluso en variadas sombras convirtiéndose en modernos trampantojos. Esto sucede con Herido en el Alba, pero también con Pavo real (Fig. 5), donde la sencillez del trazo dibujístico sobrepasa el significado del mismo. En esta línea destacan también Torero sevillano (1927) ${ }^{27}$ o Sirena (1927), convertidos en dibujos prototípicos muy defendidos por el poeta, para culminar con las tres estilizadas versiones que realizaría de San Sebastián (1927) (Fig. 6). Todos ellos y algunos más se convierten en trabajos puros y duros, son precisas creaciones intelectuales que se propone en un momento en que derrocha "sensibilidad". En una carta escrita a Gasch, confiesa que le es "difícil tenerse en pie y casi se vuela sobre el abismo"; culmina con estas palabras, que son todo un reconocimiento personal de su teoría estética: "...Estos últimos dibujos que he hecho me han costado un trabajo de elaboración grande. Abandonaba la mano a la tierra virgen y la mano junto con mi corazón me traía los elementos milagrosos. Yo los cubría y los anotaba. Volvía a lanzar mi mano, y así, con muchos elementos, escogía las características del asunto o los más bellos e inexplicables, y componía mi dibujo. Así he compuesto el Torero sevillano, la Sirena, el San Sebastián, y casi todos los que tienen una crucecita. Hay milagros puros como Cleopatra, que tuve verdadero escalofrío cuando salió esa armonía de líneas que no había pensado, ni soñado, ni querido; ni estaba inspirado,

${ }^{27}$ El interés de Lorca por la temática taurina quizás haya que relacionarlo con los dibujos de toros de Dalí, tal y como reconocía a su amigo Fernández Almagro; de hecho quiso colaborar en el libro de J. M. COSSÍO, Los toros en la poesía castellana. Estudio y antología, Madrid, 1931, en C. GARCÍA (ed.), Op.cit., p. 264. y yo dije: ¡Cleopatra! al verlo, iy es verdad! Luego me lo corroboró mi hermano. Aquellas líneas eran el retrato exacto, la emoción pura de la reina de Egipto. Unos dibujos salen así, como las metáforas más bellas y otros buscándolos en el sitio donde se sabe seguro que están. Es una pesca. Una vez entra el pez solo en el cestillo y otras se busca la mejor agua y se lanza al mejor anzuelo a propósito para conseguir. El anzuelo se llama realidad. Yo he pensado y hecho estos dibujitos con un criterio poético-plástico o plástico-poético, en justa unión. Y muchos son metáforas lineales o tópicos sublimados, como el San Sebastián o el Pavo real. He procurado escoger los rasgos esenciales de emoción y de forma, o de super-realidad y super-forma, para hacer de ellos un signo que, como llave mágica, nos lleve a comprender mejor la realidad que tienen en el mundo" ${ }^{28}$. La explicación que el dibujante realiza de su obra, es toda una declaración de intenciones respecto a su concepción del arte plástico, y nos sirve para rechazar la idea de que su obra pictórica sea simplemente divagación literaria, sino que por el contrario se convierte en auténtica metodología artística; no se queda sólo en la forma, sino que la supera; la convierte en realidad, en super-realidad, haciendo de los dibujos símbolos y signos explicativos que ayudan a comprender cada vez más una psique atormentada. No se aleja mucho de lo que supone la inhibición de la inteligencia y la voluntad, que preparan el camino para otros dibujos y creaciones más cercanas al surrealismo, aunque su arte esté plagado de objetivación y dinamismo de naturaleza como pura creación imaginativa, intuitiva, emotiva, desligada del control lógico pero con una tremenda lógica poética ${ }^{29}$.

\footnotetext{
${ }^{28}$ F. GARCÍA LORCA, Obras completas, T. III, pp. 968-969.

${ }^{29}$ V. GARCÍA DE LA CONCHA, “Introducción al estudio del surrealismo literario español", en V. GARCÍA DE LA CONCHA (ed.), El surrealismo, Madrid, 1982, pp. 17-18.
} 
CALIGRAMAS, FORMAS DESFIGURADAS Y REMINISCENCIAS DALINIANAS

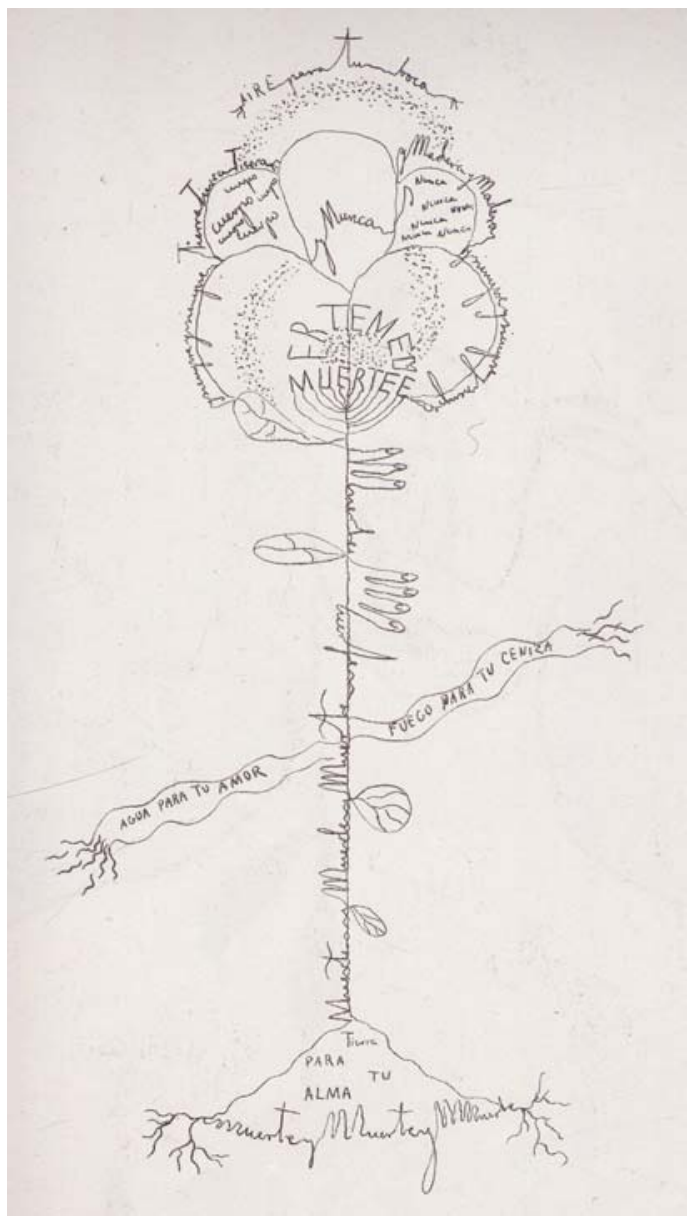

- Fig. 7. Federico García Lorca. Rosa de la muerte. Caligrama. Buenos Aires (1934). Tinta azul sobre papel. Dibujo impreso en hoja de respeto. 303 x $244 \mathrm{~mm}$. De R. E. MOLINARI, Una rosa para Stefan George, Buenos Aires, 1934. Colección Ricardo E. Molinari, Buenos Aires. Ejemplar de la Fundación Federico García Lorca, Madrid.

Lorca tiene en su hermano a un válido interlocutor, quizá porque lo considera su mejor crítico. Se convierte en un intérprete fundamental de su obra poética y dramática, pero también musical y, desde luego, plástica, a la que califica como "el espontáneo fluir de una línea obediente al instinto, libre de toda mano profesional o con la misma profesionalidad con la que escribía sus versos, utilizando la misma pluma. Llegan a formar parte de su personalidad, y lo prueba el hecho de que acabó dibujando su propia firma, en un verdadero acto de liberación caligráfica" ${ }^{\prime 30}$. Este propósito plástico-dibujístico se torna en proyección gráfica de la palabra, convirtiendo a algunos de sus dibujos en auténticos caligramas "a lo Apollinaire", de derivación ultraísta, tal vez siguiendo los consejos de Barradas. Compuso de esta manera un dibujocaligrama para el libro Una rosa para Stefan George del argentino Ricardo E. Molinari, que representaba la flor contenida en el título con la palabra "muerte" (1934) (Fig. 7) ${ }^{31}$. Coincide cronológica, formal y temáticamente con El tabernáculo, también de Molinari, que fue igualmente ilustrado por Federico. El texto del caligrama apunta lo siguiente: "Aire para tu boca / Tierra Tierra Tierra / y Madera y Madera / y siempre y siempre / cuerpo cuerpo cuerpo cuerpo cuerpo / y Nunca / nunca nunca nunca nunca nunca / y siempre y siempre y siempre / MUERTEE / MU / MUERTE MEU / Muerte y Muerte / AGUA PARA TU AMOR / FUEGO PARA TU CENIZA / Muerte y Muerte y Muerte / PARA / TU / ALMA / Muerte y Muerte y Muerte /"'32. De esta misma fecha otro caligrama titulado Mierda (1934-36), viene a corroborar el sentido poético-plástico de los dibujos-poemas al decidir ornamentarlo con líneas ondulantes que le confieren rasgos expresionistas similares al citado Bosque sexual, y cuyas connotaciones eróticas confluyen escatológicamente en la composición, abundando en el sentido de la castración. Sin romper formalmente con la abstracción, se aproxima a la metáfora del sadismo, cuyo correlato dramático se ejemplifica inequívocamente en El público y en el cristológico personaje "Desnudo rojo"; pero sobre todo en la escena en la que aparecen los personajes "Cascabeles" y "Pámpanos", donde se establece esa relación cruel que apunta (y no sólo aquí) a un tema tan surrealista como el

${ }^{30}$ F. GARCÍA LORCA, Federico y su mundo, Madrid, 1990, pp. 433-434.

${ }^{31}$ R.E. MOLINARI, Una rosa para Stefan George, Buenos Aires, 1934.

${ }^{32} \mathrm{M}$. HERNÁNDEZ, El libro de los dibujos de Federico García Lorca, Madrid, 1990, p. 234. 
sadomasoquismo: “ ¿Si yo me convirtiera en caca? / Yo me convertiría en mosca"33; alumbrándose así la naturaleza homoerótica y la verdadera angustia del amor lorquiano. Con estos poemas-dibujos, Lorca deambula entre lo terrible y premonitorio de la muerte, entre lo burlesco y lo grotesco, pero con un halo de irremediable tragedia. Es el caso también de Puta y luna (1929), un dibujo-caligrama realizado en Nueva York en el que declina la palabra "puta" (peta, pita, pota, pata), unida con una línea envolvente alrededor de un extraño animal de inequívocas connotaciones apocalípticas, y todo presidido por el astro lunar ${ }^{34}$.

El granadino seguirá componiendo dibujos-poemáticos, a la vez que mantiene una intensa correspondencia con sus amigos a los que va remitiendo algunas de sus creaciones, que en ciertos casos justifican el sentido gráfico que aquí sustituye a la palabra; como el enviado a Enrique Durán, titulado Arlequín. Poema de Federico García Lorca (1927), donde muestra una figura muy alejada de los tradicionales clowns que compone por estos años, y se aproxima más a las formas trágicas que realizaría en Buenos Aires, sobre todo, a la serie del libro de Pablo Neruda, Paloma por dentro, o sea la mano de vidrio: interrogatorio en varias estrofas, y el dibujo Imagen de la muerte (1934), por la gran semejanza que existe en la composición y en la esquelética forma que presenta el arlequín, un antecedente de la imagen de la muerte. Si bien contiene elementos surrealistas, conserva trazos y reminiscencias cubistas, representado en un rostro bicolor pero cuyas estilizadas y alargadas manos se convierten en elementos iconográficos premonitorios de los dibujos neoyorquinos. Más cercano a la estética objetivista y pura que desarrollaría en la exposición de las galerías Dalmau, destaca un poema-visual titulado Arlequín (1927), enviado a Adriano del

${ }^{33}$ F. GARCÍA LORCA, Obras completas, T. II, p. 611.

${ }^{34}$ J.L. PLAZA CHILLÓN, “El Apocalipsis según Federico García Lorca: Nueva York, 1929. Asesinatos y deseos en la ciudad muerta", en V. MINGUEZ (ed.), Las artes y la arquitectura del poder. Actas del XIX Congreso CEHA, Castellón de la Plana, 2013, pp. 1151-1168.
Valle al dorso de una tarjeta postal. Es un dibujo mucho más racional y vanguardista, alejado del exacerbado expresionismo nihilista del anterior. En esta misma carta, Lorca ruega al poeta que le escriba una crítica sobre la exposición colectiva que realizó en Huelva en 1932 junto al pintor José Caballero ${ }^{35}$. Destaca también por su filiación con la abstracción lírica Arlequín veneciano (1927), una "línea pura radiográfica"; expuesto en los célebres Carteles literarios de Ernesto Giménez Caballero como parte del cartel titulado El poeta Lorca ${ }^{36}$, cuya estilizadísima figura responde a la poética lorquiana de la palabra visual, no muy alejado del objetivismo de derivación cubista, aunque con libertad de ejecución, notándose sobre todo en los amanerados brazos y en la ladeada cabeza de prominente cabellera.

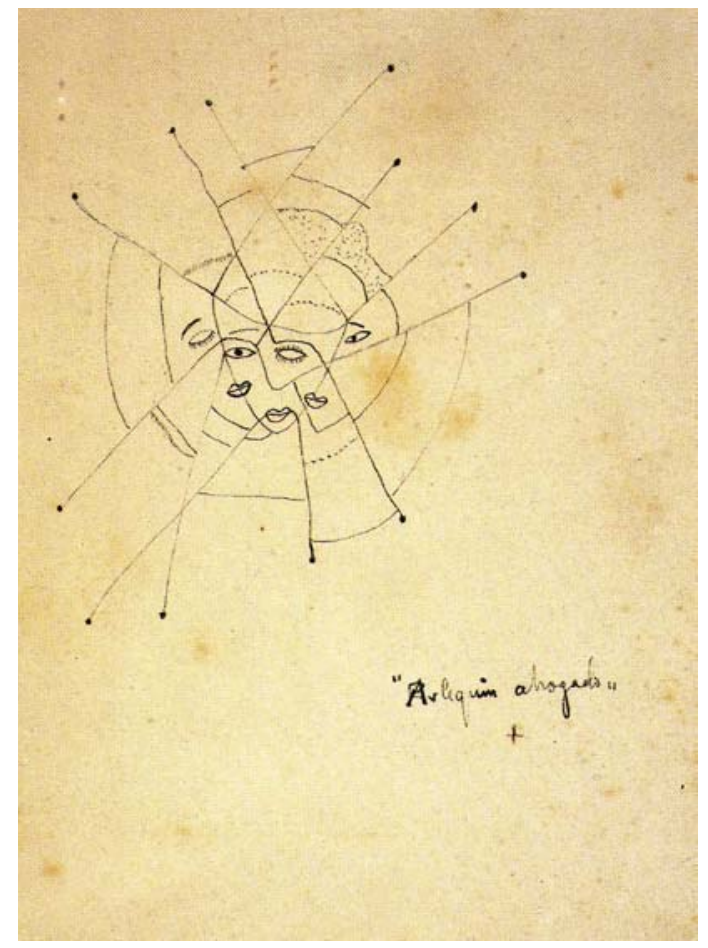

- Fig. 8. Federico García Lorca. Arlequín ahogado (ca. 1927). Tinta china sobre papel verjurado recortado. 160 x 120 mm. Colección Particular, Madrid.

${ }^{35}$ F. GARCÍA LORCA, Obras completas, T. III, pp. 696-697.

${ }^{36}$ E. GIMÉNEZ CABALLERO, “Carteles literarios", Poesía, no 26, 1986, pp. 30-62. 
El dibujo que contiene los elementos que presagian en las creaciones lorquianas los planos y las órbitas, el desdoblamiento, la multiplicación y la proyección de sombras vibrantes es el desconcertante Arlequín ahogado (1927) (Fig. 8). Su rostro se fragmenta en múltiples pedazos a modo de espejo roto que refleja una realidad última y compleja: labios pegados, ojos abiertos y cerrados, líneas que cruzan un rostro a punto de sucumbir. Federico plasma un inexplicable mundo de desdoblamiento de figuras, de personalidad rota, de iniciación al movimiento sobre una figura estática. Un rostro fragmentado que mira y duerme, un rostro que proyecta la doble tragedia lorquiana de su vida y su anunciada muerte, de su sexualidad tanática y de su Eros castrado. El dibujo contiene todo lo que de Barradas aprendió en el mundo de las artes plásticas. No es descabellado pensar en Boccioni cuando contemplamos dicha composición, ya que evoca aquellas figuras en movimiento que repiten la imagen en perfiles sucesivos, que en Federico, y como un deseo de expresión necesaria para la intencionalidad que busca, no se aleja nunca de la realidad, por eso el movimiento se inicia desde la figura estática en sí. Su intencionalidad transmite un deseo callado o encubierto, en la que surge la máscara que se multiplica con una cuidada sutileza y una belleza nada distorsionada. Se hace notar el vibracionismo barradiano, aunque más dulcificado, lejos del radicalismo cubo-futurista donde tiene su origen, con ese afán consistente en la formulación simultánea, simultaneísmo, según Barradas (y los Delaunay), de estas dos poéticas de vanguardia, que alcanzaría no sólo al ámbito plástico sino, y sobre todo, al poético: el ultraísmo. Culminaría en diversas propuestas abstractas que servían de transición entre el sustrato decimonónico y la ulterior fase de creatividad exuberante, uno de cuyos máximos representantes fue el pintor ruso Malevitch, cuyos primigenios ensayos primitivistas en un lenguaje donde predominaban las formas primarias, se mezclan con una verdadera explosión cromática y una gradación espacial tridimensional; factores, por otra parte, ajenos al cubismo, y desde luego a Federico en este caso, no tanto a Barradas, de cuya prolífica obra emanan reminiscencias rusas, pero también italianas o alemanas, países por los que viajó y cuyo aprendizaje fue esencial para el devenir de la modernidad plástica española ${ }^{37}$.

De los cuatro probables retratos que Lorca realizó de Dalí, hay tres cuya intención primordial fue captar los rasgos esenciales del rostro del pintor catalán; exceptuamos el supuesto retrato "clownista" fragmentado y semidestruido expuesto en las galerías Dalmau, el más reproducido y enigmático. Uno de los otros tres, el denominado Amor intellectualis (1927-28), nos parece el más interesante por su acusado abstraccionismo lírico, además de suponer la culminación de la iconografía dalininana interpretada por el granadino. Próximo al Arlequín ahogado pero de estirpe más clara, juega con unidades contrapuestas, cuyos planos dan lugar a un rostro dividido pero nunca fragmentado, completamente quieto, alejado del vibracionismo de los otros dibujos. Destaca entre planos geométricos el monocromo punteado del rostro, de donde sobresale un ojo con pupila negra mientras que el otro queda reducido a una sola órbita o cuenca vacía rodeada de pestañas. Lorca representa la dualidad enmascarada en apenas unas cuantas líneas, el sueño y la vigilia como contraposición a la vida y la muerte representado en un abrir y cerrar de ojos; realidad oculta en la consciente ceguera y la intención provocadora. El dibujo supone una síntesis interpretativa de la visión gráfica que el poeta tenía, al menos todavía en 1927, del pintor ampurdanés, además de representar un alejamiento cada vez más patente del geometrismo de estirpe

${ }^{37}$ Rafael Barradas y Juan Gutiérrez Gili (1919-1929). Catálogo de la exposición, Madrid, 1996. Para el movimiento ultraísta y su relación con el arte de su tiempo es imprescindible J.M. BONET (coord..), El ultraísmo y las artes plásticas. Catálogo de la exposición, Valencia, 1999. Véase, Rafael Barradas, 1914-1929. Catálogo de la exposición, Barcelona, 2004; J. URRUTIA GÓMEZ, "El movimiento ultraísta", en G. MORELLI (ed.), Treinta años de vanguardia española, Sevilla, 1991, pp. 89-100. 
cubista definido en la Oda a Salvador Dalí: “...Dice el compás de acero su corto verso elástico. / Desconocidas islas desmienten ya la esfera. / Dice la línea recta su vertical esfuerzo / y los sabios cristales cantan sus geometrías" 38 .

Lorca domina con talento determinados conceptos plásticos, desde el espacio pictórico colorista de sus dibujos escenográficos a la más pura sensibilidad de la línea, donde no había lugar para rectificaciones, ni dudas, donde la expresividad responde a un deseo claro y personalísimo criterio estético. Sus dibujos no son divertimento, no responden al ocio absurdo del aburrimiento, trascienden la realidad para convertirse en algo más profundo y sabio; salen de las manos pero llegan al intelecto. Llaman especialmente la atención los citados en la carta enviada a Gasch: Torero sevillano, Sirena o Brisa de mar; aunque existen otros similares si observamos detenidamente todo su corpus plástico. Su peculiar inventiva, a veces, nos descoloca, cuesta buscarle escuelas, tendencias, movimientos, modas o corrientes estéticas. Estas creaciones plásticas "abstractas" responden a esa idea reflexiva y universal de las formas, que artistas de todas las épocas han expresado para formular unos mismos conceptos estéticos y éticos. Formas sin definir mantenidas en el espíritu y en el tiempo, partiendo desde los signos ideográficos de la cueva del Castillo (Santander) a los grafitis marginales de cualquier urbe occidental. La insistencia en los esquematismos y enmarañamientos lineales puros retornan inconscientemente a las sinuosidades y entrecruzamientos del arte parietal prehistórico; o a alguno de los elementos orientales del arte musulmán, como apuntó acertadamente Dalí; o se sitúan en la línea de las renovadoras obras de Kandinsky y Klee. Responden a la idea atemporal del espíritu abstracto, y no se limita a obras enteramente carentes de figuración sino a una acepción mucho más amplia que culmina en el siglo XX y que denominamos esquematización intensa o semiabstrac-

\footnotetext{
${ }^{38}$ F. GARCÍA LORCA, Obras completas, T. I, p. 955.
}

ción ${ }^{39}$. Dicha expresión lorquiana no se opone dialécticamente al mundo real y existente, sus dibujos van más allá de la visibilización de la energía, de los ritmos, del orden o el desorden. Sus dibujos se alejan de las relaciones entre el ritmo abstracto y el ornamento, no son decorativos, ni gratuitos, como no lo son sus poemas, dramas o partituras musicales; proyectan una vida estética y simbólica que parecen salir del inconsciente para convertirse en reales, emanando sensibilidad y abstracción espiritual; esconden quizá una tragedia mucho más profunda y difícil de mostrar en los vericuetos del naturalismo. La abstracción o semiabstracción lorquiana, al igual que la de algunos artistas admirados por el poeta, profundiza en la práctica del arte no figurativo, tanto en teoría como en ideología, cercana a poéticas como la proximidad profunda a la naturaleza de Kandinsky o la reacción mística y nihilista de Malevitch. Ambas explican la abstracción del siglo XX, que culminaría con Mondrian y su búsqueda de lo intemporal, de la realidad pura, con la radical expresión de elementos puros. El Sketch de la nueva pintura de Lorca certifica el profundo conocimiento y la gran preocupación del poeta por su propia formación como artista plástico de vanguardia, pronunciando palabras que son auténticas sentencias: “...Ya la pintura es libre y está elevada al rango espiritual de las artes que se bastan a si mismas y que desviadas de todo agente exterior emplean todas sus resonancias en profundidad" 40 .

La presencia de Dalí en la obra lorquiana perdurará más allá de su distanciamiento; este es el caso del misterioso dibujo Labios. Walking around (1934) (Fig. 9), de la serie realizada en Buenos Aires para el libro de Neruda Paloma por dentro... Dicho dibujo muestra con extrema sencillez y mínimos recursos estilísticos siete labios unidos por sucintas líneas que parten de un punto central marcado en negro. Estos labios están representados como objetos artísticos autónomos,

${ }^{39}$ J.E. CIRLOT, El espiritu abstracto, Barcelona, 1993, pp. 9-15.

${ }^{40}$ F. GARCÍA LORCA, Federico y..., p. 461. 
cuya presencia sin aparente finalidad desprende una rara belleza de difícil definición. Los labios parecen tener carácter totémico aunque recuerdan a los objetos que convertían en arte los surrealistas, transformados en un poema donde el lívido erotismo de las bocas contrastan con el trágico punto negro del que parten. Los labios lorquianos sugieren a la vez que anticipan otros labios, pero estos más libidinosos, y que Dalí pintaría dos años después de dicho dibujo en el celebérrimo Retrato de Mae West (1936), del que haría multitud de versiones y perversiones. Con este retrato contribuye al descrédito total del mundo de la realidad ${ }^{41}$. A través del "método paranoico-crítico" es posible tener la viabilidad de una imagen doble, donde la representación de un objeto, persona o cosa, sin modificarse anatómica o figurativamente, pueda representar otra cosa absolutamente diferente sin deformidad.

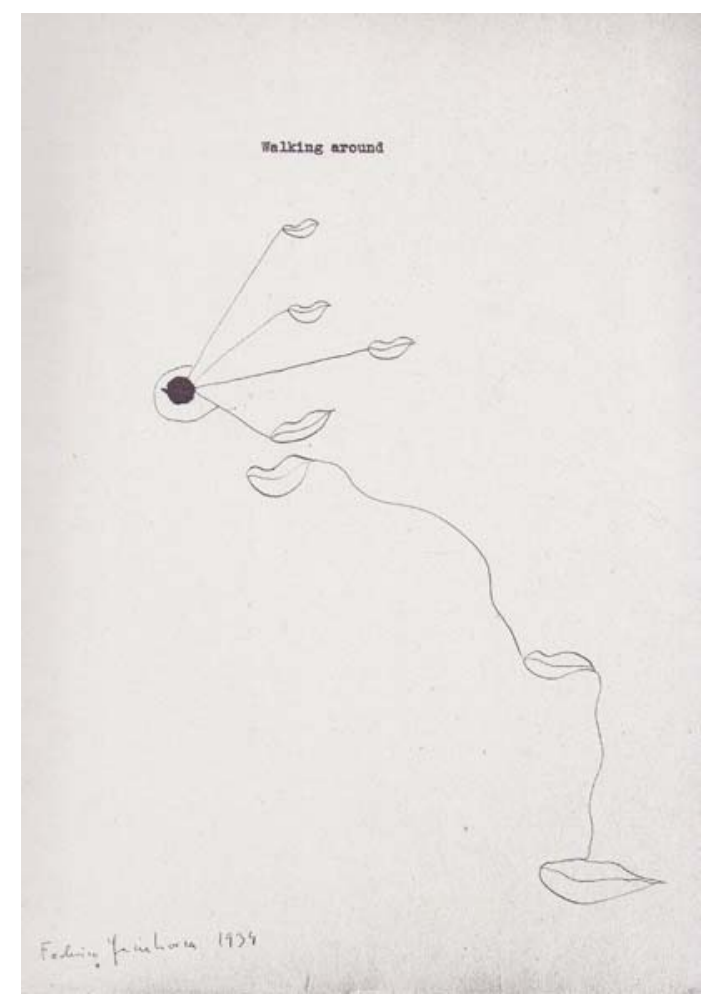

- Fig. 9. Federico García Lorca, Labios (Buenos Aires, 1934). Tinta china en portadilla del poe-

${ }^{41}$ Salvador Dalí. Rétrospective, 1910-1980. Catálogo de la exposición, Paris, 1979-1980, p. 276. ma "Walking Around", título mecanografiado; papel de dibujo amarillento. De P. NERUDA, Paloma por dentro, o sea, la mano de vidrio: interrogatorio en varias estrofas. Buenos Aires, 1934. Ejemplar único. Biblioteca Nacional, Madrid

La pintura de Dalí de la década de los años treinta se repite hasta la saciedad; su arte se convertirá en fotografía instantánea de colores, de imágenes superfinas, extravagantes, extraplásticas, extrapictóricas, inexploradas o engañosas de la irracionalidad concreta $^{42}$. El tema del doble significado o la doble incidencia practicado por Dalí a finales de la década de los veinte, se hará patente en Lorca en muchas de sus creaciones; con seguridad este influjo le había llegado a Dalí a través de Picabia, que había planteado en su obra el propio ser y su proyección, a la vez que su preocupación. Dalí pudo conocerlo en la Barcelona vanguardista de 1917, año en el que Picabia edita la revista 391, cuya redacción se encontraba precisamente en las galerías Dalmau, donde en 1922 expuso Picabia una discutida exposición presentada por el mismísimo André Breton y observada, tal vez, por Dalí. Por esta galería pasaron artistas como Braque, Dufy, Derain, Léger, Matisse, Vlaminck, Miró, Barradas, TorresGarcía, Duchamp, Glèizes, Gris o Metzinger, además de Lorca ${ }^{43}$. Allí fue exhibida El beso (1927), una de sus composiciones más complejas, con un título tan daliniano como Beso en el espejo; de referencias narcisistas, y que contiene el modelo utilizado por Dalí en alguna de sus obras contemporáneas. Como en Walking around, el dibujo centra su atención en los labios, mostrando una leve fricción, apenas un beso que el espectador tiene que codificar. Lorca se aleja de la "abstracción lírica", al menos formalmente, ya que la figuración y el colorido hacen que la composición se convierta en un auténtico poema cromático. Pinta en rojo la sombra y

${ }^{42}$ A. GONZÁLEZ GARCÍA, "El método paranoicocrítico", en A. BONET CORREA (coord.), El surrealismo, Madrid, 1983, p. 177.

${ }^{43}$ S. GASCH, "El arte de vanguardia en Barcelona", Cuadernos hispanoamericanos, $\mathrm{n}^{\mathrm{o}}$ 253-254, 1971, pp. 140141. 
su desdoblamiento al estilo Dalí, donde tal vez se superpongan las cabezas del catalán y Federico, siguiendo las mismas pautas de obras como Naturaleza muerta al claro de luna (1926-27) o Naturaleza muerta (invitación al sueño) (1926); en el primer cuadro aparecen cortadas y fundidas las cabezas de ambos artistas descansando sobre una mesa e iluminadas con un claro de luna, alusión metafórica al selénico astro lorquiano. Vuelven a reproducirse los mismos motivos aunque con mayor complejidad en Naturaleza muerta al claro de luna malva (1927) ${ }^{44}$. Existen más obras del pintor ampurdanés donde el tema recurrente y obsesivo sigue siendo su amigo, su figura y sus dobles, así en lienzos como Composición con tres figuras (Academia neocubista) (1927), Homenaje a Eric Satie (1927) o Cabeza amiba (1927), muestran esa influencia mutua que en estos años se convierte casi en una obsesión ${ }^{45}$. Intuimos que El beso representa el beso frustrado que Dalí y Lorca nunca se dieron, una historia de amor "que no pudo ser", convertida en una relación de amor-odio, de castración y sexo, de onanismo y violación..., una historia de "amor fou" con final trágico ${ }^{46}$. El dibujo contiene claros motivos formales de las pinturas de Dalí; destaca la silueta en rojo, que es la misma sombra que rodea el retrato principal; mira al espectador con lánguida tristeza, al que se superpone un rostro transparente, sin rasgos faciales cuya boca se une en un leve roce al retratado. Ese intenso rojo que mantiene la silueta se refleja en las pupilas dándole intensidad y fuerza a la mirada, además el color predomina sobre todo, ya que se esparce por la totalidad de la composición; quizá el color rojo sea un cita directa a la obra, Naturaleza al claro de luna. Llama la atención la fusión de los dos personajes en uno, que nos sugiere una identificación de la sombra recortada (la

${ }^{44}$ R. DESCHARNES, Dalí, la obra y el hombre, Barcelona /Lausana, 1984, p. 49.

${ }^{45}$ R. SANTOS TORROELLA, La miel es más dulce que la sangre. La época lorquiana y freudiana de Salvador Dalí, Barcelona, 1984, pp. 223-224.

${ }^{46}$ I. GIBSON, Lorca-Dalí. El amor que no pudo ser, Barcelona, 2000, p. 183. del propio Federico, tal vez, como autorretrato) y la transparencia, al tiempo que una fusión amorosa con el retratado (¿Dalí?). Este retrato se erige en una metáfora de la frustración amorosa entre ambos artistas.

El poeta granadino retoma soluciones plásticas e iconográficas de la pintura de Dalí, al tiempo que aprende a explorar, como hará posteriormente en el onírico mundo de los autorretratos neoyorquinos, la representación del rostro humano para mostrar su auténtica verdad; en este sentido, su fidelidad y coherencia se podría interpretar como más humana, más cercana al sufrimiento del hombre, así lo mostrará San Sebastián, que se aleja del virtuosismo enmarcado que supone la puesta en marcha del método paranoicocrítico. Será después de su ruptura con Federico cuando fraguará en Dalí toda una iconografía que madurará durante una década (1929-1939). Período definitivo donde la peculiaridad se convertirá en su auténtico estilo, basado en formas e ideas que mantendrá más o menos con altibajos hasta sus últimos días. Salvador se esforzará, aunque tal vez no sea plenamente consciente, en plasmar su sentimiento de culpabilidad, recurriendo al tema de las perversiones eróticas, ora escabrosas ora escatológicas, que provienen de su conocimiento y obsesión por Freud, descubridor de la perversidad polimórfica de la infancia, como las primeras manifestaciones de la libido y el principio del placer, convertidas en el caballo de batalla de los surrealistas. Pero este freudismo daliniano se había manifestado anteriormente a su contacto con los surrealistas franceses, que arrancó de los fastuosos días de la Residencia de Estudiantes, cuando se editaron las obras y su traducción, además de la glosa de las mismas en las páginas de la Revista de occidente ${ }^{47}$. El método "paranoico-crítico" condensa en su obra estrictamente freudiana lo más radical e influyente de su propia estética que impone con un contundente realismo basado en el engaño procedente de la vista o la visión

${ }^{47}$ R. SANTOS TORROELLA, "En torno al psicodrama daliniano", en A. BONET CORREA, Op.cit., p. 168. 
para cerciorarnos la verosimilitud de algo, pero contradiciendo la máxima de Leonardo da Vinci: "ver es saber"; por el contrario, lo que pretende demostrar es que la vista engaña, o que puede engañarnos por la vista, existiendo por tanto otra realidad no visible. Todo este complejo mundo se manifiesta en algunas de sus obras de finales de la década de los veinte, aún cargadas de reminiscencias lorquianas; desde su pintura Los primeros días de la primavera (1929), que inauguraba una serie que encandilaría a los surrealistas, diferente a todo lo que se hacía en París, como indicaba el propio Dalíi ${ }^{48}$, hasta que por primera vez muestra sus obsesiones y fantasías eróticas que tendrían su culminación en El gran masturbador (1929), donde la memoria lorquiana sigue estando presente, a la vez que enmascara el miedo a verse como homosexual. Dalí se valdría de su nuevo método en la combinación de símbolos freudianos y personales, para la expresión de sus deseos más profundos y sus violentas ansiedades, culminando de alguna manera en su voluntaria castración homosexual respecto a Lorca.

Dalí conseguirá un equilibrio entre el inconsciente y la inteligencia, e insiste en que vive una especie de regresión a la infancia sumergiéndose en el lado irracional de su personalidad, y cuyo resultado será el escandaloso cuadro El juego lúgubre (1929), donde exhibe una auténtica orgía visual que patentiza sus obsesiones sexuales. Es curioso que exista en esta pintura una evocación a Lorca, a través del pedestal que se representa en dicha obra y cuya alusión directa a las cantidades de gramo, centigramo y miligramo recuerde directamente los registros numéricos de los dibujos lorquianos Suicidio en Alejandría y San Sebastián ${ }^{49}$. Pero lo más destacable de la obra es el dibujo realizado por Lorca al dorso del citado cuadro, una composición sin fechar pero que por su abs-

${ }^{48}$ S. DALÍ, Vida secreta del Salvador Dalí, Figueres, 1981, p. 228.

${ }^{49}$ Ibídem, pp. 234-235. F. FANÉS, Salvador Dalí. La construcción de la imagen, Madrid, 1999, pp. 161. tracta estilización y trágica iconografía habría que situarlo entre 1927 y 1928. Dicho dibujo (tal vez fuera enviado por Lorca a Dalí), condicionaría a posteriori las dimensiones del cuadro; y no dudamos de que la omnipresencia inquietante de la figura lorquiana que se reproduce detrás de la tela influyera mientras éste trabajaba sobre el contenido del mismo ${ }^{50}$. La obra de Dalí está realizada al óleo y collage sobre cartón, técnica que el pintor catalán ya había utilizado anteriormente en Desnudo (1924-25), regalado a Federico. El sutil dibujo lorquiano entronca con todo ese mundo creativo que rodea a los "poemas en prosa" y los dibujos lineales ${ }^{51}$; emparentado, por tanto, a Arlequín-poema, Arlequín veneciano o el arlequín de la postal de Adriano del Valle, donde conjuga las figuras filiformes y ondulantes del cuerpo en el que asoma toda una serie de elementos fisiológicos desfigurados, además del punitivo y desafiante ojo. Esta temática habitual en el granadino de la segunda mitad de la década de los veinte tuvo que ser tenida en cuenta por Dalí al idear su Juego lúgubre, y se convirtió en una de las fundamentales de su prolífica carrera artística. Es conocida la polémica que el cuadro suscitó en la familia del pintor, que lo rechazó de pleno ante el contenido escatológico anal y sexual del mismo. La obra fascinaría a los surrealistas parisinos; Georges Bataille la estudió detenidamente, y la calificó como un "torbellino de deseos" de crispada violencia, que supuso para el grupo que lideraba Breton un carácter de revelación ${ }^{52}$. El cuadro apabulla por la cantidad de elementos que contiene referidos a la sexualidad, la escatología o el

${ }^{50}$ F. FANÉS, “El joc lúgrubre de Salvador Dalí”, Locus Amoenus, no 2, 1996, pp. 207-228.

${ }^{51}$ R. SANMARTÍN BASTIDA, “De Dalí a Lorca. El poema surrealista", Forma breve, nº 2, 2004, pp. 81-103. Uno de los críticos más influyentes de aquellos años en España consideraba la obra del catalán como "arte impuro"; en general la obra no gustó y escandalizó; E. D'ORS, "El juego lúgubre y el doble juego", La Gaceta Literaria, 15-XII-1929, nㅡ70, p. 3.

${ }^{52}$ G. BATAILLE, "Le Jeu lugubre", Documents, no 7, 1929, pp. 369-372. 
narcisismo; desde la vaginas, consideradas por el catalán como los más terroríficos orificios que existían, hasta la representación camuflada de la autoridad paterna como símbolo de la castración sexual del hijo que oculta sus deseos eróticos. También son fácilmente reconocibles otros temas habituales en Dalí como el onanismo y el vouyerismo; en definitiva, utiliza auténticas estratagemas exhibicionistas que trasparentan una ilógica inhibición sexual. La pintura, como todas las creadas en 1929, deriva del delirio paranoico llegando a los objetos surrealistas, que culminaría con su propia actividad crítica y literaria en textos paranoicos-críticos como, El mito trágico del Ángelus de Millet, Babaoua ${ }^{53}$ o Los falsos meteoros del Museo de Historia Natural, alcanzando un alto grado de convicción, con el objetivo pleno de conferir a sus interpretaciones paranoico-críticas un rango historiográfico incontestable, y desbaratar así las convenciones del gusto moderno. Esta singular poética la mantendría en obras posteriores como El hombre invisible (19291933), donde llevó a sus últimas consecuencias el método paranoico-crítico de la doble imagen. Teóricamente defendería esta teoría en una conferencia pronunciada en el Ateneo barcelonés el 22 de marzo de 1930, que escandalizó a la concurrencia, evidenciando la oposición existente entre el acto surrealista más puro posible o el hecho de dar una conferencia situada en la estricta línea del Segundo manifiesto surrealista de Breton, denunciando elementos cualificadores de la cultura catalana, a la vez que alaba el Modern Style, o las tarjetas pornográficas...; pero insiste especialmente en el carácter moral de la revolución surrealista, aunque destaque sobre todo la supremacía del placer sobre la realidad ${ }^{54}$.

${ }^{53}$ S. DALÍ, El mito trágico del Ángelus de Millet, Barcelona, 1978 y Babaoua, Barcelona, 1978.

${ }^{54}$ S. DALÍ, "Posiciò moral del surrealisme", Hélix, no 10, 1930, p. 46, traducido en, S. DALÍ, ¿Por qué se ataca a la Gioconda?, Madrid, 1994, pp. 101-104. A. SÁNCHEZ RODRÍGUEZ, "Salvador Dalí, en Torremolinos. Como y porqué se frustra la publicación en Málaga de un re-

\section{ROSTROS ENMASCARADOS}

El beso constituye un intento de retrato más cercano al realismo pese a la gran esquematización de parte de la cara; destaca su riqueza cromática y lo aleja del grupo de creaciones lineales cercanas a la abstracción. Todo lo contrario a lo que sucede con otros dos dibujos que también tienen como protagonista el rostro humano, se trata de Rostro con flechas y Rostro de las dos flechas (1935-36) (Fig. 10). Los dibujos han sido creados con apenas una línea, y quedan convertidos casi en una viñeta de máxima estilización. Sin embargo, su trasfondo poético e interpretativo puede trascender mucho más de lo que en un principio aparenta, al elevarlos al imaginario y simbólico inconsciente lorquiano para converger en un análisis semiológico y psicológico. Partimos de un presupuesto teórico común a toda la crítica de orientación psicoanalítica, de que es posible en la obra literaria desandar el camino que lleva de lo manifiesto a lo latente, a través de las recurrencias y extravagancias del sentido. De esta manera afronta el empeño como verificación analítica de una intención previa, de que toda producción dramática, poética o dibujística lorquiana se organiza sobre un triángulo de fuerzas: el llamado varón edípico, el varón viril y la mujer, desdoblada en un aspecto erótico y materno. Reproduce las constantes obsesiones que venimos analizando en su obra plástica, como el desdoblamiento de muchas de sus figuras, manifestado especialmente en los clowns que se multiplican de una manera insólita a través de la germinación del varón edípico en una proyección viril, que asume responsabilidad erótica, y que no puede afrontar por sí mis$\mathrm{mo}^{55}$.

vista del surrealismo español", El maquinista de la generación, $\mathrm{n}^{\mathrm{o}}$ 3-4, 2001, pp. 78-90.

${ }^{55}$ I. MARFUL, "Apuntes para una psicocrítica del teatro lorquiano: De la obra juvenil a las farsas" en, AA. VV., Lecturas del texto dramático. Variaciones sobre la obra de Lorca, Oviedo, 1990, pp. 47-48. 


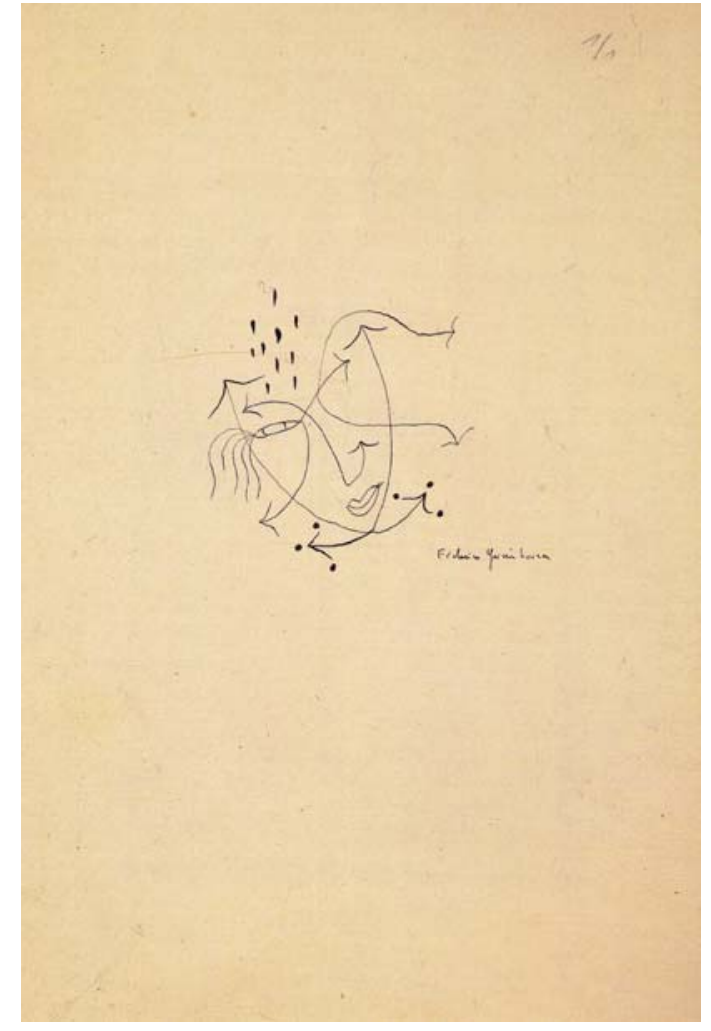

- Fig. 10. Federico García Lorca, Rostro con flechas (ca. 1935-1936). Tinta china sobre papel tela. 231 x 165 mm. Fundación Federico García Lorca, Madrid (Legado Jean Gebser).

Rostro con flechas está dibujado con un solo ojo del que emanan pequeños trazos ondulantes. El rostro está circundado por las omnipresentes flechas de los dibujos del granadino, en un total de diez, aunque emplazadas marginalmente. El otro dibujo, de composición mucho más liviana, sólo tiene dos flechas y aparece sin ojo. Poseen los dos, sin embargo, el mismo tipo de boca, con sugerentes labios parecidos al Beso y otras bocas comunes en dibujos de marineros y payasos. Intuimos que ambos representan la perenne máscara del drama lorquiano que oculta la auténtica cara como espejo del alma, máxima popular que ha pervivido a lo largo del tiempo y que ha sido corroborada por psicoanalistas contemporáneos de influencia "lacaniana", que se aleja del tópico estereotipo surrealista del automatismo y el sueño; o las tendencias que ciertos antropólogos y etnólogos hacen diferenciar el rostro de la máscara, que oculta la verdadera trans- formación. Siguiendo el interés que presenta la fisiognómica, destacamos dos tendencias: una psicológica, literaria e incluso artística, que es la que produce los resultados más valiosos; y otra sistemática, codificadora y dogmática, que hace que se asocie con técnicas esotéricas, como la quiromancia o la astrología. Lo que en psicología práctica y arte puede ser un elemento valioso para caracterizar, se convierte en un saber, una gnosis que, como las antes indicadas, conduce a un fatalismo casi absoluto ${ }^{56}$. En el mundo de la modernidad contemporánea el estudio del rostro, aceptando criterios orgánicos generales, presta más atención a lo fisiológico y móvil, y busca el modo de establecer una teoría general de la expresión de las emociones. El rostro, como sede de la expresión de las emociones, es potencialmente la parte más obscena del cuerpo humano ${ }^{57}$; en este sentido, hay artistas que utilizan el dominio o destreza del dibujo para componer tratados en el que se reflejan las pasiones u otros sentimientos íntimos; tal vez, no sea del todo el caso de los dibujos lorquianos, pero sí apuntan, siguiendo los dictámenes del drama o incluso a la luz de la mímica, a la representación de cada rostro de un tipo de fuerza, buscando un ideal. Hay sin duda en los sucintos rasgos faciales dibujados una parte teatral y que de algún modo son extrapolables a otros dibujos como Máscara y rostro (1935), portada del Llanto por la muerte de Ignacio Sánchez Mejías, dedicado al pintor Juan Antonio Morales (cartelista de Yerma) y que al igual que los otros dos contiene toda la esencia de la tragedia y del drama que esconde el propio rostro del poeta.

Los tres dibujos, a pesar de la economía de medios, sugieren dolor y una profunda tristeza; ambiguamente el poeta dibuja un corazón a través del rostro donde precisamente va a dar la flecha referida en la glosada carta dirigida a su amigo Sebastián Gasch; además estos corazones-rostros contienen

${ }^{56}$ J. CARO BAROJA, La cara, espejo del alma. Historia de la fisiognómica, Barcelona, 1987, p. 74.

${ }^{57}$ R. GUBERN, La imagen pornográfica y otras perversiones ópticas, Madrid, 2004, p. 127. 
los hirientes dardos que los hacen llorar o sangrar. Se produce esa bipolaridad común en el imaginario lorquiano, sol-luna; siendo el corazón una abreviatura del sol, símbolo del arquetipo paterno, de dios, y de todo lo que nos gobierna. Aunque también pudiera ser un símbolo de la caverna como diosa-madre, de la fecundidad nocturna y húmeda, de la luna acogedora, protectora y a la vez verdugo de nuestra muerte, y todo regado con la lluvia natural convertida en lágrimas sobre unos rostros prácticamente $\operatorname{cegados}^{58}$.

El ojo es considerando por muchos psicoanalistas posmodernos como símbolo del vientre materno y la pupila como su hija, tal vez no sea aventurado aplicar a Lorca las interpretaciones llevadas a cabo por Jung, y que en estos dibujos pueden tener absoluta validez. La mujer sin hijo o infecunda (advirtamos las esterilidades dramáticas de Yerma, Dª Rosita o Mariana) es una mujer oscura, negra, metafóricamente sin pupila; precisamente una gran parte de los dibujos que representan figuraciones humanas son realizados sin pupilas, y si bien por un lado, esto responde a una cuestión estética o formal (cubismo o vibracionismo), no debemos desdeñar que cuando Lorca utiliza determinados temas iconográficos, como en el caso de San Sebastián, recurre a la inconsciencia simbólica del mundo de la sexualidad y sus consecuencias sobre la fertilidad; no en vano el término "parir" o "dar a luz", comporta la misma idea ${ }^{59}$. En los dibujos de los "rostros con flechas", uno carece de pupilas y el otro de ojos (los dos), faltándole por tanto el alumbramiento de la vida.

Las flechas son los otros protagonistas de los dibujos, en uno más que en otro. Dichos elementos son una constante en la iconografía plástica lorquiana, unas veces presentadas como auténticos paralelepípedos lineales, otras, las más, se retuercen en multitud de curvas ondulantes impregnando todo el dibujo. Flechas que tienen multitud de

\footnotetext{
${ }^{58}$ C. AREÁN, "Dibujos de un poeta cromático", Cuadernos hispanoamericanos, № 433-434, 1986, p. 115.

${ }^{59}$ C. J. JUNG, Símbolos de transformación, Barcelona, 1990, p. 268.
}

lecturas, según la composición gráfica o dibujo referido; aquí se presentan de trazado único e inequívoco, enmarañando el "rostro con flechas", mientras que en el otro dibujo sólo dos puntas se unen en una sola. Flechas que aparecen como pequeños rayos de sol, o que se unen para formar una nariz con marcado carácter fálico. El ojo sugiere también un simbolismo fálico, o la equivalencia entre ceguera completa de un rostro y castración plena de la sexualidad. La boca por el contrario refleja lo máximo de la tristeza en el poeta granadino, tratada íntimamente y vivida en soledad.

No es casualidad que estos rostros de delicadas formas abombadas se asemejen a sencillos y poéticos corazones; son además contemporáneos de los homoeróticos y místicos Sonetos del amor oscuro; conmovedores poemas en los que su única sombra, tal vez, sea el regazo del vientre materno, la búsqueda de la cueva uterina o el regazo de la luz lunar; sonetos de acogimiento, de amor trágico y triste, como lo son estos tres visionarios dibujos. Reflejan también los dibujos la traslúcida luz del amor y del sexo que esconden los sonetos; el amor concebido como una permanente búsqueda, un deseo que continuamente causa herida, por eso la voz del poeta aparece crispada y estremecida ${ }^{60}$. A pesar de su extrema pureza, en los sonetos también aparecen elementos fisiológicos corporales que habían sido abandonados plásticamente a finales de la década de los veinte: herida, cintura, mordiscos, boca, gemido, muslo, sangre, aliento, pecho, carne estremecida, fuego, llanto, llama, garganta, corazón, agonía, alma mordida, boca rota de amor, mejilla... Son los sonetos la expresión de ese cuerpo, de la voz hecha cuerpo, que alterna presencia y ausencia: “...Goza el fresco paisaje de mi herida, / quiebra juncos y arroyos delicados. / Bebe en muslo de miel

${ }^{60} \mathrm{C}$. NEWTON, "Los paisajes del amor: iconos centrales en los sonetos de Lorca", Anales de literatura española contemporánea, $\mathrm{n}^{\circ}$ 11, 1986, pp. 143-159. M. HERNÁNDEZ, "Jardín deshecho: los sonetos de García Lorca", El Crotalón, no 1, 1984, pp. 193-228. 
sangre vertida..." ${ }^{61}$. En los sonetos la pasión amorosa conduce a la destrucción, al aniquilamiento, aunque no domine la muerte como en las composiciones neoyorquinas, los poemas en prosa o El público. En estos poemas la preponderancia es la vida, aunque una vida con amor dolorido y terrible soledad, el amor convertido en un terrorífico monólogo sin interlocutor; voz solitaria surgida del deseo, que se convierte en cruel porque está cerca de su propia castración: “...Llena, pues, de palabras mi locura / o déjame vivir en mi serena / noche del alma para siempre oscura" ${ }^{62}$.

Lo fisiológico como tema constante en la creación plástica lorquiana, al igual que en su poesía y parte de su drama, llama la atención por los símbolos más primitivos e instintivos, en un camino iniciado radicalmente en los poemas en prosa, y que culmina con el ciclo de las aportaciones gráficas neoyorquinas y sudamericanas. Precisamente de las fechas que corresponden a la estancia en la ciudad norteamericana, se sitúa uno de los dibujos más logrados del granadino, La vista y el tacto (1929-30) (Fig. 11), que constituye la representación de los dos sentidos predilectos del poeta; así lo declaraba en la conferencia escrita sobre Luis de Góngora a propósito del tema: “Un poeta tiene que ser profesor en los cinco sentidos corporales. Los cinco sentidos corporales, en este orden: vista, tacto, oído, olfato y gusto. Para poder ser dueño de las más bellas imágenes tiene que abrir puertas de comunicación en todos ellos y con mucha frecuencia ha de suponer sus sensaciones y aun de disfrazar naturalezas. [...] La vista no deja que la sombra enturbie el contorno de la imagen que se ha dibujado delante de ella. Ningún ciego de nacimiento puede ser un poeta plástico de imágenes objetivas, porque no tiene ni idea de las proporciones de la Naturaleza [...]. El tacto enseña la calidad de sus materias líricas. Su calidad casi pictórica. Y

\footnotetext{
${ }^{61}$ F. GARCÍA LORCA, Obras completas, T. I, p. 939.

${ }^{62}$ Ibídem, p. 942.
}

las imágenes que construyen los demás sentidos están supeditadas a los dos primeros ${ }^{163}$.

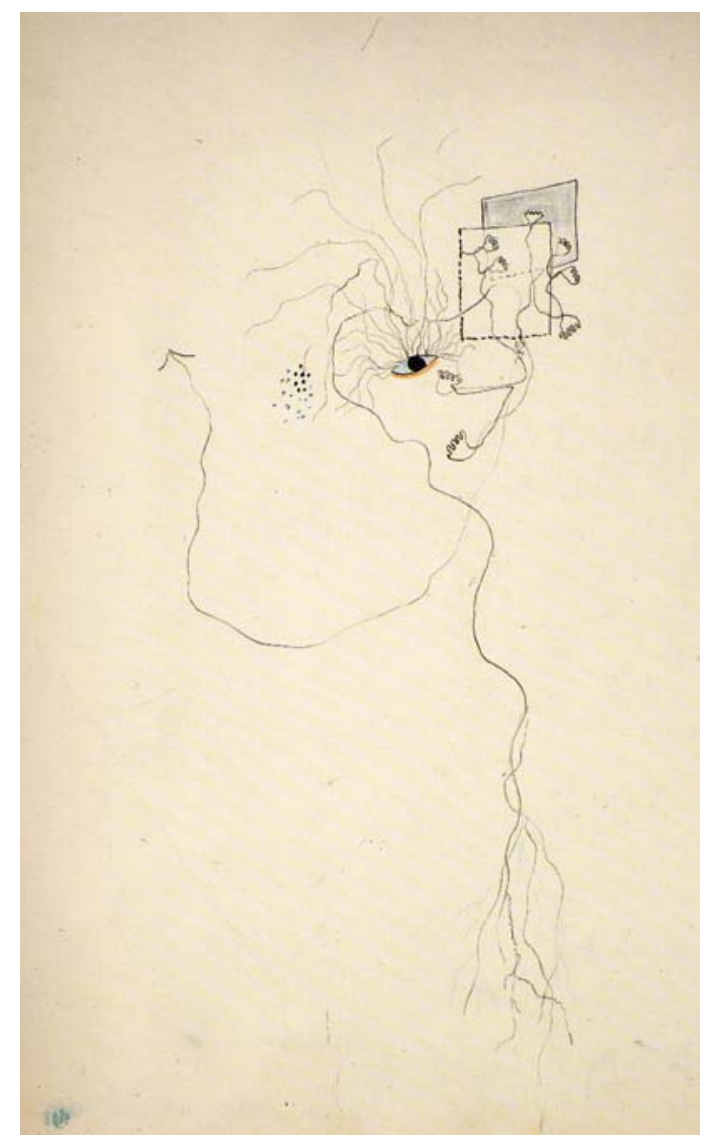

- Fig. 11. Federico García Lorca, La vista y el tacto (ca. 1929-1930). Tinta china y lápiz azul y rojo sobre papel. 252 × 202 mm. Fundación Federico García Lorca, Madrid (Legado Jean Gebser).

No todo lo señalado por Lorca se resuelve con la unión de dos sensaciones opuestas, o en el dibujo, con imágenes contrarias, que a través de una astucia mental conlleva a la disolución del cuerpo en el lenguaje, donde lo fisiológico y lo simbólico se confunden ${ }^{64}$. Como en San Sebastián, Ecce homo, Animal fabuloso dirigiéndose a una casa, y Ojo y pie sobre un plano, el ojo abierto es el centro de atención y elemento medular del dibujo La vista y el tacto. A diferencia de los

\footnotetext{
${ }^{63}$ Ibídem, T. III, pp. 229-230.

${ }^{64}$ N. LY, "Lorca y la teoría de la escritura: La imagen poética de Luis de Góngora", en AA. VV., Valoración actual de la obra de García Lorca, Madrid, 1988, p. 171.
} 
ojos cegados, sin pupilas o con las cuencas vacías, lo más señalado es precisamente la órbita ocular apuntando incluso la cuenca de la misma. La pupila, en un intensísimo color negro, marca la atención y vida del ojo central, vigilante, observador, sostenido por un sinuoso trazo que termina en multitud de líneas a modo de pestañas gigantes y trágicas. Aparece el elemento sígnico de la flecha, aunque en solitario, como una daga que busca a su víctima. También lo fisiológico, venoso y celular queda reflejado en las débiles terminaciones entrecruzadas a modo de pestañas, que vuelven a ramificarse como raíces dendríticas en la parte baja del dibujo. En el plano que se superpone a la derecha del ojo, queda invadido por una serie de diminutas e inválidas manos surgidas en un auténtico juego entrelazado; manos que apenas se insinúan, más bien, se descomponen en hallazgos líricos semiabstractos, que se repetirán en posteriores obras, como la enigmática Imagen de la muerte (1934), pero donde resurgirán incipientemente nerviosos grafismos que delimitan y atraviesan cuerpos, apareciendo curiosamente como único ojo apto para la visión, el que acompaña la flor, los demás están vacíos, muertos.

El dibujo lo interpretamos como una proyección gráfica de la teoría lorquiana planteada en la conferencia sobre Luis de Góngora, de la relación de la poesía con los sentidos, en este caso el de la vista y el tacto, manifestados pictóricamente en el ojo y las pequeñas manos. Curiosamente, sus líneas muestran la misma jerarquía de los sentidos: vista, tacto, oído, olfato y gusto. Los tres primeros relacionados con la parte superior del cuerpo, y por tantos eminentes, mientras que los otros dos, el olfato y gusto, se ligan a la parte inferior del cuerpo, considerados como menores. El hecho de ofrecer ocho manos frente al ojo implica la necesidad de tenerlas para producir el efecto de un único ojo. Los dos planos pueden sugerir ventanas o espejos, sobre todo, el oscuro, cuyos indicios indican la absoluta oscuridad del reino de la vista ( "ningún ciego puede ser un poeta plástico", decía Lorca) y lo real solamente puede configurarse con el espejo del ojo. Así como nos reconocemos cuando nos miramos al espejo, el ojo se convierte en elemento primordial para conocer su interioridad. Encontramos una equivalencia poética de este dibujo, donde aparecen elementos fisiológicos como ojos, ramificaciones celulares, manos o espejos humanos, en los versos de El niño Stanton del poemario norteamericano que refleja con angustia la monotonía de la vida vacía: "...Mi dolor sangraba por las tardes / cuando tus ojos eran dos muros, / cuando tus manos eran dos países / y mi cuerpo rumor de hierba..." 65 .

García Lorca hace del ojo una fuente de luz, y como la luz es símbolo de inteligencia, la acción de ver, que no mirar, representa un acto espiritual que simboliza entendimiento, y, desde luego, conocimiento. Mientras que los ojos que aparecen vacíos y sin pupila reflejan ignorancia, oscuridad, tristeza, tragedia o muerte; los ojos con pupila son iluminadores, alumbradores y lúcidos, dando forma y adquiriendo una realidad plástica en sus dibujos, quizá el ejemplo clarificador de todo, esté contenido en un solo verso del neoyorquino poema Nocturno del hueco: "Toda la luz del mundo cabe en un ojo" $^{\prime 66}$. Estos juegos visuales y la presencia del ojo saltan con alta frecuencia de una obra plástica, a la poesía y al teatro, desde Poema del cante Jondo a Poeta en Nueva York, pasando por Romancero gitano, o desde La casa de Bernarda Alba a El maleficio de la mariposa, donde todo está escrito y pensado para ponerse en escena visto a través de los ojos de insectos, así el ojo humano mira la obra a través del ojo del personaje animal; un juego óptico de espejos con una forma visual que antecede al ojo surrealista en 1920 y en la proyección de un ambiente no humano, materializándose en estos ojos de la madurez creativa lorquiana ${ }^{67}$.

\footnotetext{
${ }^{65}$ F. GARCÍA LORCA, Obras completas, T. I, p. 495.

${ }^{66} \mathrm{Ibídem,} \mathrm{p.} 506$.

${ }^{67}$ M. BALBOA ECHEVARRÍA, Lorca: El espacio de la representación. Reflexiones sobre surrealismo y teatro, Barcelona, 1986, pp. 39-40.
} 


\section{LORCA, MIRÓ Y EL LIRISMO PICTÓ- RICO}

Observamos la radicalización que Lorca imprime a sus obras plásticas, dotándolas de una capacidad de abstracción cuyos juegos de líneas, ora se alejan, ora se acercan al mundo de la realidad compartida. Es relativamente fácil establecer comparaciones de algunas composiciones analizadas respecto al cercano mundo de Dalí u otros pintores de estéticas análogas como Óscar Domínguez, Max Ernst, o Yves Tanguy, que vivieron el surrealismo como un auténtico estado puro del espíritu. En el automatismo de André Masson, la pintura-poética de Miró, Magritte y la pintura pesimista (tan cercana conceptualmente a García Lorca, especialmente en los temas del doble y la máscara), Tanguy con sus panoramas desolados o el naturalismo orgánico de lo descriptivo de Ernst, se pueden hallar paralelismos estéticos con el mundo plástico lorquiano ${ }^{68}$. Insistimos en la relevancia que la huella daliniana y los vanguardistas catalanes tuvo en la obra plástica de Federico, que afectó además a su concepción teórica del arte; así se aprecia en el Sketch de la nueva pintura o en las distintas misivas enviadas a Gasch, en las que notamos ciertas resonancias surrealistas sobre el automatismo o el "soñar despierto", a la vez que incide en la validez de cualquier visión en estado de vigilia para estimular la elocuencia del inconsciente y la necesidad de representarla con la técnica realista más minuciosa ${ }^{69}$.

En general, sus creaciones plásticas parecen buscar la expresión de un orden espiritual, íntimo, particular y universal, que lo transporta, y en cierto modo, antecede a un nuevo concepto estético generalizado después de la II Guerra Mundial denominado "abstracción lírica", que lo aleja de otras abstracciones de origen cubista, constructivista o neoplasticista. Su abstracción como su lírica 1965.

${ }^{68}$ A. BRETON, Le surrealisme et la peinture, Paris,

${ }^{69}$ F. CALVO SERRALLER, "Los dones artísticos del duende", El País, 19-VIII-1986 (Extra "Lorca", cincuentenario de la muerte del poeta), p. VIII-IX. es poética, y por tanto musical, de notable riqueza emotiva, sensible a las turbaciones del espíritu, pero donde es posible rastrear la angustia de la propia existencia como acto puro. Con todo, es un concepto un tanto ambiguo de definir, y conviene subrayar la gran dificultad que encierra compendiar de forma concluyente dicha "abstracción lírica", que tendrá un enorme éxito en los años cuarenta y cincuenta, y a la que se adherirán distintas tendencias o denominaciones como la pintura de acción, el expresionismo abstracto, el informalismo, la pintura matérica, el arte "autre", el "dripping" y toda una utilización determinada del signo y de la escritura basada en las enseñanzas orientales del zen (recuérdense las reflexiones de Dalí o Gasch sobre la filiación de los dibujos lorquianos con la epigrafía oriental $\mathrm{y}$ árabe-caligráfica $)^{70}$. Estas tendencias fueron practicadas por una gran variedad de artistas en la segunda mitad del XX como Michaux, Soulages, Mathieu, Wols, Tobey, Kline, Pollock o Hartung, tan próximo, éste último, en algunas de sus composiciones al granadino ${ }^{71}$.

García Lorca con sus dibujos abstractos se aleja, sin embargo, del contenido esencial del abstraccionismo planteado con posterioridad por estos pintores, sobre todo, en su concepto de marginalidad de la historia, negando la concepción del individuo hasta entonces vigente. Ignoran todo aspecto positivo en la búsqueda de una función social de la actividad estética, precisamente por evitar o neutralizar la propuesta de valores históricos, que aún estando al margen de las contingencias temporales, fueron volcados hacia un futuro previsible. Desde el punto de vista del lenguaje, Lorca se aproxima a este particular planteamiento abstracto y lírico, en el sentido del aprovechamiento máximo de las disponibilidades de la materia, así como las del signo o el gesto; pero en cualquier caso se

${ }^{70}$ S. DALÍ, "Frederic García Lorca: Exposició de dibuixos colorits (Galeries Dalmau)", La Nova Revista, no 9, 1927, pp. 84-85. S. GASCH, "García Lorca dibujante", La gaceta literaria, 15-III-1928, pp. 4-5.

${ }^{71} \mathrm{G}$. DORFLES, Últimas tendencias del arte de hoy, Barcelona, 1966 y El devenir de la crítica, Madrid, 1978. 
opone la eventualidad del orden racional en beneficio de una expansión preeminente de la turbulenta intimidad individual.

Siguiendo esta conceptualización, es Miró el artista cuyos planteamientos estéticos se aproximan más al de Fuente Vaqueros; sobre todo, la obra que domina gran parte de la década de los veinte, donde el lirismo, la linealidad e incluso la tragedia se intuyen en pinturas como Perro ladrando a la luna (1924) o Los amantes $(1928)^{72}$. Una obra creada en los límites de la abstracción y que representa un arte de esquemática reducción primitivista. Algunos críticos como Gasch, le negaban esta categoría, y se inclinaban más bien por una opción personal basada en invenciones propias, creando formas e impulsos entrañables asociadas a una rememoración de lo real reducida a elementos puros, sin la presencia del objeto, como sucede en los dibujos de Federico. Miró elimina la apariencia buscando estrictamente la esencia, alejándose de la pura abstracción al concebir sus obras como una visión interior. Estos planteamientos ingenuistas están contenidos en gran parte de la obra plástica lorquiana. Breton lo reconocía como el "más surrealista de los pintores"; sin embargo su solución pictórica era mucho menos compleja, tal vez, por su acercamiento a la función natural ${ }^{73}$.

La realidad llega a su pintura por el camino de la poesía. Consigue dar a las formas un movimiento que comunica con el mundo sensible sin someterse a la apariencia. Formas concordantes con esa oscura percepción realizada desde su visión interior, por eso los surrealistas lo contaron como suyo. En el Sketch de la nueva pintura, Lorca lo situaba como el más universal de los pintores españoles, a pesar de su juventud, cuyo arte resultaba difícil de clasificar, aunque fuese el más "puro que se ha intentado desde que los hombres cogieron los pinceles". Su afirmación resulta categórica, y lo ubica en el devenir histórico

72 P. GIMFERRER, Las raíces de Joan Miró, Barcelona, 1993. J. PERUCHO, Joan Miró y Cataluña, Barcelona, 1968.

${ }^{73}$ V. COMBALÍA, El descubrimiento de Miró. Miró y sus críticos, 1918-1929, Barcelona, 1990. contemporáneo, dentro de un terreno donde domina la estética pura. Observemos las siguientes palabras dictadas sobre la obra de Miró en la conferencia de 1928: "Este paisaje nocturno donde hablan los insectos unos con otros, y ese otro panorama, o lo que sea, que no me importa saberlo ni lo necesito, están a punto de no haber existido. Vienen del sueño, del centro del alma, allí donde el amor está en carne viva y corren brisas increíbles de sonidos lejanos. Yo experimento ante esos cuadros de Miró la misma misteriosa y terrible sensación que siento en los toros en el momento en que clavan la puntilla sobre la testa del hermoso animal. Momento en que nos asomamos al borde de la muerte que clava su pico de acero en el tierno e intangible temblor de la materia gris"74. Lorca sitúa al catalán en el terreno de los "sobrerrealistas", y le dedica su comentario más extenso; probablemente Gasch le contagió parte del entusiasmo por Miró, aunque había algo de interés propio, de cercanía de mundos. El granadino ofrece un comentario de empatía desbordada, situando al pintor ajeno a la valoración surreal, enfatizándolo todo con un final donde confluyen: amor, belleza, emoción y muerte.

Esta misma atención que le dedica cobrará forma en sus dibujos, así la pureza de Miró por lo instintivo y sexual, junto a la voluntad extrema de abstracción lírica será obtenida mediante el trazo límpido y grácil sobre fondos temblorosos de color. Sin ese contexto plástico mironiano, inseparable del mundo de la poesía, sería difícil de entender dibujos como Brisa de mar, Torero sevillano, Pavo real, Labios, Rostro de las flechas, Serenata o Sirena; dibujos líricos que muestran la fuerza de la poesía y de la pintura. Al igual que en Miró, la minuciosidad y la atención no estorban, de esta manera el artista sirve al poeta y viceversa. Tanto Miró como Lorca, Cocteau o Max Jacob, imaginan que el estilo no puede ser un punto de partida, y se afanan por hallar el ápice de certeza existente más allá de la verdad misma, confiando en la in-

${ }^{74}$ F. GARCÍA LORCA, "Sketch de la nueva pintura", en F. GARCÍA LORCA, Federico y su..., pp. 465-466. 
quietud para acceder a mejores formulas pictóricas $^{75}$. El sentimiento poético infunde a las imágenes una disponibilidad en la que yacen múltiples posibilidades de transformación, según la mirada o el espectador. Miró como poeta y pintor es maestro de la técnica donde el color se convierte en lenguaje, pero la línea es convertida en pura palabra proyectada, dando un empuje lírico a sus lienzos que los hace vibrantes y expresivos; en este sentido, $\mathrm{y}$ ante sus primigenias telas, e incluso en sus lienzos posteriores, es innegable el ejemplo musical, que hace sentir la vibración de las propias telas, como señalaba Paul Klee ${ }^{76}$.

El tema de las relaciones entre Miró y el arte sonoro ha sido objeto de distintos acercamientos, al tiempo que se han señalado las conexiones del fenómeno musical y la inspiración mironiana y su afinidad personal con algunos compositores como John Cage o Stockhausen, además de las relaciones en el terreno de la creación escénica ${ }^{77}$. En repetidas ocasiones Miró mencionó sus preferencias musicales: Bach, Schumann, Wagner, o compositores contemporáneos como Falla, Stravinsky o Ravel, sin olvidar el jazz u otras músicas no occidentales. Refiriéndose a su etapa surrealista de la segunda mitad de los veinte en óleos como La siesta (1925) (Fig. 12) o Musique, Seine o Bataille et moi (1927), no tiene reparo en definirlos como "campos sonoros... de ritmos caligráficos y musicales", y que parecen definir también los dibujos-línea de Lorca ${ }^{78}$. Declara Miró: “... La música siempre me había atraído y ahora, en este perío-

${ }^{75}$ R. GULLÓN, De Goya al arte abstracto, Madrid, 1972, p. 99.

${ }^{76}$ G. GAN QUESADA, “Miró-músicas. Resonancias musicales de los espacios mironianos", en Actas del XV Congreso Nacional de Historia del Arte (CEHA): Modelos, intercambios y recepción artística (de las rutas marítimas a la navegación en red), Palma de Mallorca, 2008, Vol. 1., pp. 721-736.

${ }^{77}$ E. JUNCOSA, "Joan Miró i la música", Estudis baleàrics, no 47-48, 1993-1994, pp. 39-48. M. GUAL, “Miró. Escenografía y color", Danza 79, no 36,1984, pp. 19-23. Miró en escena. Catálogo de la exposición, Barcelona, 1994.

${ }^{78}$ M. ROWELL (ed.), Miró. Escritos y conversaciones, Valencia / Murcia, 2002, p. 388. do [después de la guerra civil española], la música empezó a tomar el papel que la poesía había desempeñado al principio de los años veinte" ${ }^{\prime \prime 79}$. Miró en 1928 ilustró el libro de Lise Hirtz, Il était una fois una petit pie, y a partir de ahí realizaría una serie de composiciones músico-pictóricas basadas en estas ilustraciones; obras que, consideradas como "musicalidad interna, han de ser el punto de partida hacia las telas partiendo de formas musicales, obras en las que el sentido de la musicalidad se acentuará y deberá precederlas en su ejecución" ${ }^{80}$. Existen multitud de casos similares de apropiación pictórica del fenómeno sonoro por parte de Miró, aunque esté cobijado por un espacio ritual resonante que determina taxativamente su aprehensión y significado, si bien en los últimos años de su producción se haría menos evidente, sin estar apoyada además en testimonios del pintor; al contrario del encuentro creador en los años de las vanguardias, donde confluyeron el poeta y el pintor: Lorca y Miró ${ }^{81}$.

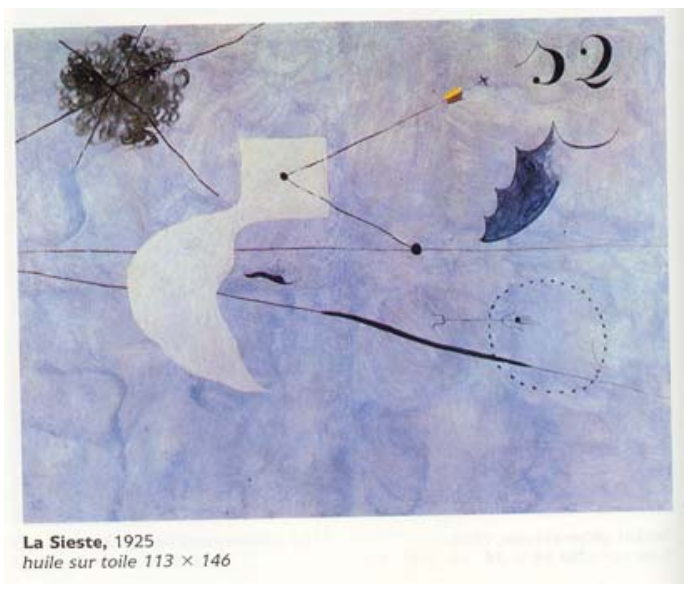

- Fig. 12. Joan Miró, La siesta (1925). Óleo sobre lienzo, 113x145 cm. Museo Nacional de Arte Moderno, Centro Georges Pompidou, París.

En Miró hay un predominio de poesía, inseparable siempre de la pintura; el catalán leerá a poetas como Apollinaire, Tzara, Char, Reverdy o Eluard, pero sin duda al que más

\footnotetext{
${ }^{79}$ Ibídem, p. 294.

${ }^{80}$ Ibídem, pp. 114-125.

${ }^{81}$ R. PENROSE, Miró, Barcelona, 1993, pp. 107-108.
} 
debe es a Rimbaud, como reconoció en más de una ocasión; quizás sus obras se hagan más legibles si acudimos a los versos del heterodoxo poeta francés ${ }^{82}$. Miró admiraba profundamente uno de sus sonetos más conocidos: Vocales, uno de los poemas más influyentes de la literatura contemporánea. El poema ha sido sometido a múltiples exégesis, entre las que destacamos dos: la interpretación sinestésica (relación forma-color) y la interpretación alquímica (relación con las sucesivas fases que conducen a la consecución de la "piedra filosofal"). Existe una similitud entre el poema y un sistema tántrico de concentración en el que cada "chakra" (centros de energía corporales) se corresponde con un sonido y con un color; así por ejemplo uno de los métodos podría establecerse de la siguiente manera: OM-para luz blanca; I-violeta; E (gutural)azul... El tema de la equivalencia entre colores y movimientos del alma, encierra el hermético significado de este poema de Rimbaud que tanto fascinaba al catalán: "A negra, E blanca, I roja, $\mathrm{U}$ verde, $\mathrm{O}$ azul: vocales, / algún día diré vuestros nacimientos latentes..." ${ }^{83}$.

La pintura de Miró como los dibujos de Lorca son obras de sensaciones e intuiciones, por eso el granadino explicaba a Gasch que sus dibujos eran "plástica-poética" o viceversa. Quizá esta indeterminación responda a lo borroso de las intuiciones. Por ello los dibujos desfigurados tienden a desnaturalizar una lógica de interpretación, ya sea por la poesía que los impregna o por un cierto alejamiento de la realidad, aunque mantiene siempre un equilibrio en su modo creativo. Insiste Lorca en sus cartas enviadas al crítico Gasch que se encuentra en un estado de gracia o inspiración pictórico-poética, y dibuja sin cesar. Cuando realiza estas declaraciones no está haciendo un mero juego de palabras, ya que el catalán había llamado la atención sobre esta tendencia en la nueva pintura europea tras el cambio de sensibilidad mediada la década de los veinte,

82 G. RAILLARD, "El surrealismo arraigado en Miró", en A. BONET CORREA (ed.), Op.cit., pp. 138-139.

${ }^{83}$ A. RIMBAUD, Poesías y otros textos. (ed., y notas de J. ABELEIRA) Madrid, 1995, pp. 305-307. denominada como "vuelta al instinto" y que albergaba posiciones individuales o tendencias organizadas, hoy bastante desconocidas, como el "neorromanticismo" o la "figuración lírica", que había sido apoyada por el crítico galo Tériade, leído y glosado por el granadi$\mathrm{no}^{84}$. Tanto el francés como Gasch defendían un nuevo arte plástico y poético, alejándose del surrealismo más ortodoxo. Por plástico se entendía la facultad de mantener los principios de una pintura pura que no renunciara a la sugerencia figurativa, y por poético, la capacidad de actuar desde el enamoramiento de los materiales pictóricos por sí mismos ${ }^{85}$, cuyo resultado final podría entenderse como una nueva forma de primitivismo que forzosamente llevaba a la pintura de signos. Existe, por tanto, una aproximación de Lorca a los planteamientos europeos del momento en esta vuelta "pictórica al instinto" que cuadraba en el horizonte del paradigma del artista para la nueva pintura. El principio de la pintura pura analizada aparece unida a los poemas en prosa, donde lo intuitivo y espontáneo se convierten en elementos de irradiación, y así lo muestra en sus dibujos, que reflejan todo lo aprendido conceptualmente de la pintura pura con la acción liberadora del instinto y la espontaneidad. Lo plástico-poético se convertía en una especie de redundancia, así lo genuinamente plástico era poético en sí, y viceversa. Lorca con sus dibujos se encuentra a sí mismo y puede encauzar su propia verdad y su vitalismo en el fluido creador, que en este caso se transforman en auténticas composiciones plásticas y que podrían pertenecer a cualquiera de los grandes pintores de aquellos años ${ }^{86}$.

${ }^{84}$ J.M. DÍEZ BORQUE (coord.), Imagen en el verso: del siglo de oro al siglo XX. Catálogo de la exposición, Madrid, 2008

${ }^{85}$ E. TÉRIADE, “La pintura de los jóvenes en París", La gaceta literaria, no 24, 15-XII-1927, p. 7; y "París. Los nuevos pintores", La gaceta literaria, no 9, 1-V-1927, p. 5. Sus escritos teóricos están publicados en A. TÉRIADE, y M. ANTHONIOZ, M. SCHMIDT (Pról. e introd.), Tériade. Écrits sur l'art. Paris, 1996.

${ }^{86}$ E. CARMONA (coord.), Pintura fruta. La figuración lírica española. 1926-1932. Catálogo de la exposición, Madrid, 1996. 